ANUARIO DE Estudios MEDIEVALES 42/2, julio-diciembre de 2012, pp. 697-725

ISSN 0066-5061

doi:10.3989/aem.2012.42.1.06

\title{
BEATAS Y COMUNIDAD CÍVICA. ALGUNAS CLAVES INTERPRETATIVAS DE LA ESPIRITUALIDAD FEMENINA URBANA BAJOMEDIEVAL (CÓRDOBA, SIGLOS XIV-XV) ${ }^{1}$
}

\author{
BEGUINES AND CIVIC COMMUNITY. \\ SOME INTERPRETATIVE KEYS \\ OF LATE MEDIEVAL URBAN FEMALE SPIRITUALITY \\ (CORDOBA, 14th-15th CENTURIES)
}

MARÍA DEL MAR GRAÑA CID

Universidad Pontificia Comillas (Madrid)

\begin{abstract}
Resumen: Frente a la habitual imagen historiográfica que presenta al movimiento religioso femenino bajomedieval como falto de coherencia y determinado por fenómenos de excedencia socioeconómica de mujeres, estas páginas plantean la importancia del análisis de su característica conexión con las ciudades para valorar sus fisonomías, formas asociativas e intencionalidades $\mathrm{y}$, consiguientemente, la dimensión política de la espiritualidad femenina urbana. Se centran sobre un sector del movimiento, la vida beata no reglada y, dentro de un marco andaluz especialmente potente en manifestaciones religiosas femeninas, en la ciudad de Córdoba, epicentro reformista durante los dos últimos siglos medievales.
\end{abstract}

Palabras clave: movimiento religioso femenino; beatas; ciudades medievales; vecindad; comunidad cívica; feminismo medieval.

\begin{abstract}
In the light of the usual historical image presenting the late medieval female religious movement as lacking coherence and being determined by the phenomenon of a socio-economic female surplus, these pages raise the importance of the analysis of its characteristic connection with the cities in order to evaluate their features, associative forms and intentions and, consequently, the political dimension of urban women's spirituality. The focus is on one sector of the movement, namely the non-regulated religious life, considered within an Andalusian framework that was particularly conspicuous in female religious expression: the city of Córdoba, reformist epicenter during the last two centuries of the Middle Ages.
\end{abstract}

Keywords: female religious movement; beatas; medieval towns; vicinity; civic community; medieval feminism.

\footnotetext{
${ }^{1}$ Abreviaturas utilizadas: ACC $=$ Archivo Catedral de Córdoba; AHPC $=$ Archivo Histórico Provincial de Córdoba; AHPCProt = Archivo Histórico Provincial de Córdoba, sección Protocolos notariales; ASC = Archivo del monasterio de Santa Cruz de Córdoba; ASNV = Archivo de la parroquia de San Nicolás de la Villa de Córdoba; carp. = carpeta; $\mathrm{CMC}=$ Manuel Nieto Cumplido, Corpus Mediaevale Cordubense, tomos inéditos; cuad. = cuaderno; leg. = legajo; ms. = manuscrito; perg./ pergs. $=$ pergamino/pergaminos; $\mathrm{RAH}=$ Real Academia de la Historia.
} 


\section{SUMARIO}

1. Introducción.- 2. Coordenadas históricas y socio-espirituales del fenómeno beato no reglado en Córdoba.- 3. Amor, hermandad y vecindad.- 3.1. Las agrupaciones beatas.- 3.2. Un proyecto evangélico de relación entre los sexos.- 3.3. En pro del bienestar social: caridad, trabajo y oración.- 3.4. La vecindad como vínculo articulador del movimiento religioso femenino.4. Regeneración eclesial y significación trascendente de la comunidad cívica: el peso femenino en la ciudad.- 4.1. Una sociedad femenina en el cuerpo urbano.- 4.2. Al servicio del ideal de comunidad cívica.- 5. Reflexiones finales.- 6. Bibliografía citada.

\section{INTRODUCCIÓN}

La conexión con las ciudades fue uno de los aspectos más característicos del movimiento religioso femenino ${ }^{2}$ bajomedieval, ese fenómeno de incremento espectacular de las mujeres consagradas a Dios y sus espacios inspirado por espiritualidades de signo evangélico que ellas potenciaron y modelaron con rasgos propios dando origen a nuevas formas de vida y planteamientos teológicos con un horizonte común de regeneración religiosa y socioeclesial. En su sentido sociológico, se entiende por movimiento: Un intento colectivo por promover un interés común o por asegurar una meta común mediante una acción colectiva que quede al margen de la esfera de las instituciones establecidas ${ }^{3}$.

Sin embargo, domina una imagen historiográfica de falta de coherencia del movimiento femenino: un sector muy importante lo ha valorado en términos estrictamente socioeconómicos, como resultado de la "excedencia" femenina característica de la estructuración social urbana bajomedieval, y también se ha visto asociado a nociones de "anarquía" por carecer de estructuras formales y, supuestamente, de criterios conformadores ${ }^{4}$. Son cuestiones todavía abiertas y poco estudiadas para el ámbito hispano. En estas páginas planteo el análisis del vínculo entre el movimiento religioso femenino y la ciudad en una doble dirección de interinfluencias y en una dimensión que, más allá de lo socioeconómico, busca planteamientos políticos. En mi opinión, ésta sería una de las principales claves explicativas del fenómeno ${ }^{5}$. Me centraré en un sector del movimiento, el beato no reglado, y, dentro de un marco andaluz especialmente potente en manifestaciones religiosas femeninas ${ }^{6}$, en la ciudad de Córdoba, epicentro reformista durante los dos últimos siglos medievales.

${ }^{2}$ Entre la numerosa bibliografía, la obra clásica de H. Grundmann, Movimenti. También R. Rusconi, Il movimiento, entre otros muchos.

${ }^{3}$ A. Giddens, Sociology, p. 511.

${ }^{4}$ C.W. Bynum, Fragmentation, pp. 63-65; A. Benvenuti, "In castro", p. 116. Para Herlihy, las beguinas fueron "mujeres sin un lugar, sin una familia o un convento que las anclase en la sociedad" y constituyeron un "amplio pero desorganizado movimiento" de mujeres religiosas "irregulares" -D. Herlihy, Opera, p. 67. Para Manselli, es visible la falta de unidad orgánica y coherente del movimiento femenino. R. Manselli, La Chiesa, p. 259. Un ejemplo especialmente llamativo en el énfasis sobre la carencia de criterio común: D. Bornstein, Donne, pp. 244-245. Sobre la superfeminización demográfica urbana, Y. Barel, La ciudad, pp. 222 y ss. Son conocidas también las operaciones de desprestigio a que se vio sometida esta forma de vida. Véase, por ejemplo: P. Santonja, Mujeres, pp. 209-228.

${ }^{5}$ Estas consideraciones en relación con el entero fenómeno del movimiento religioso femenino, en M.M. Graña, Religiosas.

${ }^{6}$ Para algunos autores fruto del "barroquismo" religioso andaluz. J. Sánchez Herrero, La religiosidad, p. 330. Un panorama reciente de la vida religiosa femenina laica en la Sevilla bajomedieval, en S.M. Pérez González, La mujer. 


\section{COORDENADAS HISTÓRICAS Y SOCIO-ESPIRITUALES DEL FENÓMENO BEATO NO REGLADO EN CÓRDOBA}

Entre 1363 y 1464 nació y se desarrolló en Córdoba un movimiento reformista laico de carácter no reglado y con un mayoritario protagonismo femenino concretado en una nueva forma de vida religiosa, la beata. La dedicación religiosa de carácter penitencial-evangélico por parte de mujeres laicas in domibus propriis o en las casas de otros particulares, representantes bajomedievales de un género de ascetismo doméstico con larga historia en la Iglesia ${ }^{7}$ revitalizado en el Pleno Medievo al calor de las espiritualidades reformistas ${ }^{8}$ y orientado en los siglos bajomedievales a las formas más personalizadas de la Devotio Moderna, fue un fenómeno complejo. Etimológicamente, su denominación remite al término latino beatus-a-um y a sus significados "feliz" o "dichoso". Como fundamento religioso, la vocación de vivir en servicio de nuestro Señor Dios ${ }^{10}$ bajo una inspiración evangélico-apostólica, lo que implicaba una opción penitencial que podía alcanzar niveles de intensa radicalidad ascética en ayunos y mortificaciones corporales; una también intensa actividad orante individual-mental de tipo afectivo con amplios márgenes de libertad y autonomía en la relación personalizada con Dios; un compromiso de castidad que en Córdoba figura como preferente opción por la virginidad consagrada al ser mayoritariamente solteras las beatas documentadas, sobre todo en las dedicaciones individuales ${ }^{11}$; y una actividad de cura animarum ejercida en formas varias de servicio comunitario, aunque con el tiempo se tendió al recogimiento. En su origen fue de carácter estrictamente laico y privado, independiente de las instituciones religiosas y eclesiásticas y carente de normativas escritas.

Si durante el último tercio del siglo XIV se concretó de forma individual, en fecha indeterminada posterior a 1400 debieron nacer las primeras comunidades o beaterios cordobeses ${ }^{12}$. Entre 1464 y 1471, culminando el proceso, se documenta el mayor número de beaterios y beatas ${ }^{13}$ pero, al tiempo, la generalización de un fenómeno de institucionalización fruto de otras coordenadas históricas que no voy a tratar aquí y que había ofrecido un primer y aislado indicio en 1455 con el primer beaterio fundado por una agente externa, Cárdenas de San Andrés, en el que ya se reglamentaron por escrito algunas de las actividades de sus integrantes ${ }^{14}$.

Resulta impactante el gran peso específico, numérico en un primer golpe de vista, que las beatas tuvieron en Córdoba, así como su diversidad de fisonomías en contraste con su paralelo -en lo cronológico y en los fundamentos espirituales de base- fenómeno religioso laico masculino concretado en los ermitaños de la sierra.

\footnotetext{
${ }^{7}$ Hay referencias al menos desde el siglo IV. G.G. Meersseman, I penitenti, p. 308; S.F. Wemple, Women, p. 155.

${ }^{8}$ Sobre el ideal espiritual apostólico de corte evangélico y su inspiración reformista: M.D. Chenu, El despertar, pp. 478-505.

${ }^{9}$ La etimología y sus significados, en M. Palacios, Las beatas, pp. 110-111.

${ }^{10}$ AHPCProt, Oficio 14, leg. 1; CMC, 1464-2.

${ }^{11}$ M.M. Graña, Religiosas, p. 282.

${ }^{12}$ Hubo sintonía en este sentido con otras áreas andaluzas y europeas. Así lo ha señalado J.M. Miura, Formas, pp. 139-164.

${ }^{13}$ Es muy difícil señalar cifras concretas por la dispersión informativa, pero a lo largo del siglo XV hay noticia de, al menos, veintitrés beaterios y un número indefinido de beatas individuales repartidas por la ciudad de las que es posible documentar cuarenta y una. M.M. Graña, Espacios, v. I, p. 356.

${ }^{14}$ AHPC, Clero, pergs., carp. 8, núm. 1.
} 
Las referencias a beatas individuales superan con mucho las noticias sobre ermitaños $\mathrm{y}$, sin duda, el beaterio constituyó en la gran urbe la principal forma de asociacionismo laico.

Es importante la clave explicativa demográfica, especialmente operativa en grandes aglomeraciones superiores a 5.000 vecinos como Córdoba, donde podría considerarse un fenómeno estructural. Figura ligado a feminizaciones demográficas muy características de las ciudades medievales ${ }^{15}$ aunque no esté claro si como cauce de regulación poblacional. La historiografía utiliza el término "superfeminización" para nombrar un desnivel demográfico con predominio cuantitativo de mujeres, general -el conjunto de una sociedad-o parcial -sectores como el de los pobres ${ }^{16}$. Nuestras dificultades informativas son grandes. Los padrones de tipo fiscal o militar, representativos de una parte de la realidad al documentar sólo a los vecinos cabezas de familia, arrojan porcentajes de vecinas muy inferiores a los de vecinos en la Andalucía del siglo XV, aunque el número de viudas habría aumentado en su último tercio y el primero del XVI a causa de la guerra de Granada, epidemias y malas cosechas ${ }^{17}$. Por lo demás, la secuencia repoblación-despoblación-crisis dio lugar en Córdoba a un contexto de precariedad poblacional donde pudo darse un predominio femenino propiciado por la defensa de la frontera y la continuación del avance militar. El análisis de la vida religiosa sugiere la feminización de la pobreza, sobre todo en la segunda mitad del siglo XIV. Después no hay noticias tan explícitas, aunque muchos de los beaterios surgidos por el tejido urbano acogieron mujeres pobres, carentes de techo propio o enfermas, con presencia de viudas entre las creadoras de nuevos grupos ${ }^{18}$. Además, el beato fue un fenómeno religioso de predominante soltería femenina $(97,4 \%$ respecto a otras dedicaciones) que coincidió en su origen con la primera fase de superación de la crisis y que sólo adoptó una fisonomía comunitaria en los inicios del desarrollo demográfico ${ }^{19}$.

Sin embargo, la indudable conexión demográfica no lleva a explicar el fenómeno beato exclusivamente en esta clave y mucho menos en términos de excedencia. Las cifras religiosas contradicen las estimaciones parciales de la población local, que señalan un desequilibrio de la sex ratio a favor de los varones y una tasa de natalidad más baja entre los sectores artesanales que entre las aristocracias durante el siglo XV, lo que no se corresponde con el hecho de que fueran mujeres del medio artesanal sus iniciadoras y de que los beaterios, en general más ligados a estos sectores populares, fueran el espacio religioso con mayor número de solteras. Además, soltería y excedencia no iban necesariamente unidas, como probaría la situación del sector nobiliario cordobés, con menor número de mujeres pero cifras más elevadas de celibato entre ellas $^{20}$. Y es sintomático que el auge demográfico del último tercio del XV coincidiese con la drástica disminución creadora de beaterios.

Otra clave explicativa habitual ha sido la interinfluencia entre espacios religiosos por considerar factores de peso el establecimiento de techos demográficos y

15 Y. Barel, La ciudad, pp. 222 y ss.

16 P.H. Cullum, “And Hir Name”, p. 200.

17 A. Collantes, Sevilla, p. 150; M. González Jiménez, El concejo, p. 40.

${ }^{18}$ En continuidad con ello se situarían las medidas proteccionistas adoptadas en el siglo XVI. RAH, ms. 9/5436, f. 731v; ms. 9/5434, ff. 322r-337r; ACC, caja V, núm. 369; RAH, ms. 9/5436, f. 732v. En el siglo XVI ellas habrían sufrido más el pauperismo, sobre todo en las capas populares: J.I. Fortea, Córdoba, p. 176; A. Mackay, Averroístas, p. 250.

19 J.M. Escobar, Córdoba, p. 285; C. Flores, La evolución, pp. 97-125.

${ }^{20}$ I. Beceiro, R. Córdoba, Parentesco, pp. 165 y 169, n. 167; M.C. Quintanilla, Estructuras, pp. 342 y 345-346; M. Cabrera, Nobleza, pp. 344-345, 347 y 320. 
la exigencia de dote en los monasterios, clave que ha conllevado la desvalorización de la vida beata, considerada solución menor ante la imposibilidad del ingreso monástico. Pues bien, en Córdoba no hubo correspondencia entre el establecimiento de un techo demográfico en el único monasterio femenino por entonces existente, Santa Clara, y el origen de las beatas, que fue posterior. A título comparativo aunque exceda nuestra cronología, la eclosión monástica de finales del XV, acompañada del establecimiento generalizado de techos demográficos, no provocó el aumento de beaterios por tratarse precisamente del momento de su disminución y reorientación. Respecto a la imposibilidad de pagar una dote, el hecho de que muchas beatas fueran propietarias muestra que, aun pudiendo darse dicho fenómeno, tampoco fue determinante.

Hubo, además, una nítida diferenciación sociológico-religiosa entre monjas y beatas no regladas. Éstas se identificaron preferentemente con el común de la ciudad, el sector pechero, frente al origen mayoritariamente aristocrático de las monjas. Aunque la carencia de padrones de cuantías obstaculiza el análisis del amplio y heterogéneo sector de los pecheros, base de la pirámide social ${ }^{21}$, y aunque también se planteen dificultades de clasificación al contar en la mayor parte con simples menciones de nombre y apellidos no identificables (91\%), es posible afirmar que éstos fueron eminentemente populares; la escasez de adscripciones concretas invita a pensar en los sectores menos acomodados del grupo pechero, aunque en ocasiones sí hay menciones al artesanado y a situaciones de pobreza y marginación social.

La extracción sociológica ofrece diferentes matices en función de su carácter individual o comunitario. Así el gran peso específico del sector artesanal entre las beatas individuales ${ }^{22}$ y su inferioridad numérica en los beaterios aunque cualitativamente esta adscripción social fue muy importante en sus orígenes. Hubo una evolución cronológica tendente a su aristocratización. Fue notoria la intensa identificación originaria entre los primeros beaterios y los sectores populares-artesanales, así como su tendencia en la fase inmediatamente posterior a los concejiles inferiores, en concreto a jurados con apellidos no aristocráticos; este segundo vínculo se explicitó en la denominación de algunos beaterios y se sobreentiende en otros dadas las conexiones de parentesco ${ }^{23}$. Durante el último tercio del siglo XV, fuera de nuestro estudio, aparecieron las referencias a profesiones liberales y los indicios, no bien documentados, de vinculación con la oligarquía urbana ${ }^{24}$. En líneas generales, la elevación sociológica

${ }^{21}$ Puede subsanarse la laguna acudiendo a estudios de poblaciones que sí cuentan con ellos, como Jaén: J. Rodríguez Molina, Los no privilegiados, pp. 133-163.

${ }^{22}$ Hijas de aladreros, de esparteros, armeros y cerrajeros; primas de correeros, hermanas y tías de colcheros. ACC, caja G, núm. 117; CMC, 1491, t. 2; AHPCProt, Oficio 18, leg. 5, f. 120r; ASC, cajón $7^{\circ}$, pieza $4^{\mathrm{a}}$, instrumento $10^{\circ}$; AHPCProt, Oficio 14 , leg. 1 ; Oficio 14 , leg. 3 , cuad. 2 , ff. $173 \mathrm{v}-174 \mathrm{r}$; Oficio 18, leg. 2, ff. 637r-638r.

${ }^{23}$ Los ejemplos son bastante numerosos y se refieren a un número variado de profesiones: albañiles, perailes o asteros -ASNV, San Jerónimo, núm. 140, leg. 2, n. 31, núm. 35; CMC, 1428; AHPCProt, Oficio 14, leg. 6, cuad. 1, f. 40v; ASC, cajón $6^{\circ}$, pieza $2^{\mathrm{a}}$, entre otros. El vínculo con jurados se detecta en los dos beaterios ligados a la familia Armenta, en las beatas de Santa Marina y quizá en las Calderonas ya que en 1442 uno de los jurados de Omnium Sanctorum era Pedro González Calderón. Sobre este último, M. Cabrera, Nobleza, p. 128.

${ }^{24}$ Las beatas Beatriz Fernández y Marina Rodríguez Buenosvinos eran hermanas del bachiller Juan Ruiz de Buenosvinos, fiscal del oficio de la Inquisición de Córdoba (1496) -AHPCProt, Oficio 18, leg. 5, ff. 549r-553r; ASNV, San Jerónimo, núm. 27, leg. 1, núm. 30; CMC, 1496, t. 3. El apellido Godoy ostentado por dos hermanas beatas formaba parte de la oligarquía local -F. Ruano, Casa de Cabrera, pp. 290 y ss. Ha de considerarse que los vínculos artesanales podían combinarse con otros privilegiados y que la adscripción social resultante es difícil de valorar: Beatriz Fernández era hermana del carpintero Antón Rodríguez y tía del canónigo Pedro de Aranda (1496) -AHPCProt, Oficio 14, 
coincidió con la transformación de las formas de vida hasta la especialización: vida activa - $\mathrm{O}$, cuando menos, abierta- y libre entre los sectores populares y tendencia al recogimiento parcial o pleno entre los aristocráticos en sintonía con procesos de cerrazón y control vocacional en la vida beata.

Las dedicaciones laicas femeninas han solido caracterizarse como intercla$\operatorname{sistas}^{25}$, pero en el caso cordobés se percibe un fenómeno matizado por la cronología. La predominante coexistencia de mujeres con diferentes niveles económicos, "pobres o ricas" 26 aunque procedentes de un mismo sector no privilegiado, fue adquiriendo rasgos interclasistas -0 , quizá mejor, interestamentales- según se tendió a la aristocratización. Este rasgo se plasmó de formas diversas en función de los tipos organizativos comunitarios, como luego se verá.

La identificación beata con el común urbano se pone igualmente de manifiesto al analizar su proyección sociorreligiosa, con un marcado interés por las mujeres. Pese a lo fragmentario de la información, el beaterio del Cañuelo ofrece datos durante buena parte del siglo XV y también las beatas de Armenta y beatas individuales. El apoyo popular fue todavía más notorio durante el último tercio de la centuria y favoreció a las comunidades no regladas que habían logrado sobrevivir pese a las presiones institucionalizadoras, siendo esta continuidad de proyección una de las posibles razones de su pervivencia: así los beaterios de Ruy González o de Santa Marina y, especialmente, el del Cañuelo. Ambos, además de concitar las preferencias de los vecinos de la ciudad como intermediarios salvíficos ${ }^{27}$, pudieron servir como referencia de enterramiento en una interesante función de sacralización de espacios urbanos que desvela la integración de los cementerios en los ámbitos de proyección e influencia religiosa beata ${ }^{28}$.

\section{AMOR, HERMANDAD Y VECINDAD}

Las beatas desarrollaron vínculos que nacieron de su ideal evangélico de communitas y que situaron en el centro de su experiencia dos grandes manifestaciones: por un lado, las conectadas con el amor, como este mismo, la caridad y la hermandad; por otro, las que las ligaban a la ciudad, especialmente una noción de vecindad que no cabría entender en una dimensión jurídica sino vivencial-residencial.

leg. 32, cuad. 20, ff. 53r-55v-. Entre los ejemplos de beatas individuales, doña Leonor de Sotomayor era hija del veinticuatro Pedro Méndez de Sotomayor. AHPCProt, Oficio 14, leg. 8, cuad. 4, ff. 4r-6v; F. Ruano, Casa de Cabrera, p. 193.

${ }^{25}$ Así desde el estudio clásico de H. Grundmann, Movimenti.

${ }^{26}$ Según afirmación de Elvira de la Cruz. RAH, ms. 9/5436, ff. 657r-664v.

27 Este fenómeno fue muy visible entre 1480 y 1500. Las beatas del Cañuelo acaparaban los encargos de oraciones en 1488, en 1496 y 1499; desde 1483 atestiguamos encargos de oraciones a las beatas de Ruy González mantenidos en 1494, 1496 y 1498. AHPCProt, Oficio 14, leg. 22, cuad. 5; leg. 29 , cuad. 3 , ff. 1r-5v; leg. 32, cuad. 18, ff. 11v-13r; leg. 35, cuad. 19, ff. 27v-30v; leg. 18, cuad. 4, ff. 1r-2v; leg. 29, cuad. 11, f. 10r-v; leg. 32, cuad. 16, f. 48r; leg. 35, cuad. 19, ff. 20v-24v.

${ }^{28}$ En 1488 una beata mandaba enterrarse en "el monesterio de Santa Marina" -en referencia al beaterio de Ruy González-, delante de la puerta de San Miguel -AHPCProt, Oficio 14, leg. 23, cuad. 8, ff. 31v-32r. Se trataba de una de las puertas de la iglesia parroquial de Santa Marina, la que estaba próxima al beaterio, y sabemos que por esa zona se emplazaba el cementerio parroquial porque a estas mujeres se las menciona también como "beatas que están frente del cementerio", AHPCProt, Oficio 14, leg. 23, cuad. 6. 


\subsection{Las agrupaciones beatas}

Los beaterios no fueron familias espirituales al uso -tal y como se concebían en la vida monástica-, sino la suma de individuas que libremente decidían convivir -y que con libertad podían marcharse si así lo deseaban- y en la que se resaltaba la hermandad -incluso con la superiora del grupo o "hermana mayor" 29 - sustentada sobre el amor y la paz internos. Un concepto de hermandad y concordia que pudo estar basado en un pacto. Esto no se documenta, pero son notorios los paralelismos con la noción contemporánea de hermandad política urbana, un concepto de profunda raigambre concejil que tenía larga historia -al menos desde el siglo XIII ${ }^{30}-$ y un notorio componente defensivo de intereses y libertades, así como de pacificación política ${ }^{31}$. Por otra parte, el gran peso específico de la consanguinidad como pauta organizativa beata -sobre todo en un segundo momento- ofrece paralelos con otras formas urbanas de asociacionismo como las agrupaciones mercantiles y financieras fundadas en la alianza de hermanos ${ }^{32}$.

En los primeros beaterios cordobeses parece percibirse la plena coparticipación organizativa y económica. La casa era compartida por las denominadas beatas "bizocas", que empleaban términos de igualdad para referirse a su propiedad y a la responsabilidad económica del pago de deudas. Esto, sumado al hecho de tratarse de la comunidad más antigua y de la que ofrecía planteamientos espirituales más radicales, sugeriría la posibilidad de un funcionamiento igualitario y consensuado en términos evangélicos de hermandad al estilo de los grupos más radicales de los movimientos apostólicos ${ }^{33}$, independientemente de que una de sus componentes figurase al frente ${ }^{34}$. Con todo, pronto tendieron a una realidad jerarquizada de carácter económico y sociológico. El tipo más habitual muestra diferencias en el seno comunitario. Solía tratarse de grupos surgidos en torno a una sola y principal propietaria -o varias hermanas propietarias-, diferenciada socialmente del resto, que aportaba la residencia y se encargaba de la dirección y regulación comunitaria, pero que seguía siendo la dueña de la casa o ponía sus condiciones para que las beatas la disfrutasen tras su muerte. Este tipo mostró una doble variante vitalicia y perpetua.

Los beaterios vitalicios, sin afán de perdurabilidad, ofrecen el paralelo más claro con otras hermandades contemporáneas, de duración limitada ${ }^{35}$. Podían ser comunidades espontáneas de componentes similares en cuanto a su origen social donde las superioras eran las mayores propietarias de los bienes comunes, o bien beaterios familiares creados por una o varias hermanas, que eran sus dirigentes y máximas propietarias. En el primer caso, las dueñas -Santa Marina, jurado Nicolás Rodríguez-, legaron las casas a sus compañeras de forma vitalicia para pasar después a otras personas o instituciones. En el segundo, el concepto de sororidad sólo se percibe entre las hermanas de sangre, que, organizadas de forma mancomunada, podían compartir la propiedad y se situaban en un nivel superior respecto a las demás dado su origen preferentemente bajonobiliario - parientas de jurados con apellido reconocible- frente

${ }^{29}$ Denominación documentada en otras áreas geográficas: A. Muñoz, Beatas.

${ }^{30}$ M. Asenjo, Concordia, pp. 131 y 135; J.M. Nieto Soria, Los prolegómenos, p. 43.

${ }^{31}$ Bien demostrado en los ejemplos eclesiásticos conocidos. J.M. Nieto Soria, Los prolegómenos, p. 46.

32 J. Heers, El clan, pp. 251-258.

${ }_{33}$ M.D. Chenu, El despertar, p. 502.

${ }^{34}$ Isabel Fernández, probablemente en su condición de "mayor"; quizá por eso ponía sus bienes personales al servicio común. ASNV, San Jerónimo, núm. 140, leg. 2, núm. 31, núm. 35; CMC, 1428.

${ }^{35}$ Como las eclesiásticas, J.M. Nieto Soria, Los prolegómenos, p. 63. 
al popular de éstas. Las hermanas se sucedían en la dirección o ejercían un liderazgo conjunto $^{36}$. Cabe la sospecha de que este tipo estuviese mucho más extendido; desde luego, fue muy característico de los microbeaterios -de dos componentes-, agotados con la muerte de sus protagonistas. Aunque no necesariamente, pudo ser importante el referente familiar y convertirse el apellido en la seña identificativa del grupo -beatas de Armenta, Calderonas-. En ambos tipos tuvo gran peso el vínculo de acompañamiento ${ }^{37}$.

La otra vendría representada por los beaterios perpetuos, que ofrecen dos versiones. Primera, el surgido de una situación similar a los anteriores, una propietaria que ponía la casa, pero que aseguraba su perdurabilidad en su testamento. Así las beatas del Cañuelo residentes en las casas legadas a toda la comunidad por Leonor Fernández de Armenta, su primera hermana mayor; como contrapartida, designaba expresamente a quien había de sucederle en el ejercicio de "la mayoría", Marina Rodríguez o "Marina la Grande", distinguiéndola con una participación doble en la propiedad -las partes correspondientes como "mayor" y como beata- aun cuando las demás también fuesen titulares de la misma; se trataba de un ejemplo de transmisión de propiedad entre mujeres, las herederas eran las religiosas que componían la asociación, no ésta en sí, pues no había afanes de perdurabilidad institucionalizados, sino fundados en una genealogía femenina que era la que garantizaba la subsistencia, forma de actuación que sus sucesoras mantuvieron ${ }^{38}$. Quizá como subtipo deberían incluirse las "recreaciones" de beaterios mediante la reglamentación y dotación de comunidades ya existentes a fin de garantizar su perdurabilidad, fenómeno propio del siglo XVI. El segundo tipo sería el de las fundaciones propiamente dichas, con la intervención de un agente externo.

Como se ve, en los beaterios no plenamente coparticipativos, los más numerosos, la propiedad de la residencia solía llevar aparejado el gobierno del grupo, lo que acostumbró a coincidir también con la concentración de los bienes con que se sustentaba el beaterio y que sus titulares gestionaban de forma independiente, sin ejercer como representantes de la comunidad. Aunque no en todos los casos, por lo común estas diferencias organizativas vinculadas a la distribución de la propiedad reflejaron diferencias sociales al ser las propietarias de las casas parientas de jurados y sus compañeras mujeres de sectores medios-populares, en algún caso artesanales ${ }^{39}$, sin que se documenten ejemplos de ejercicio directivo fruto de un posible carisma religioso. El factor cronológico debió ser decisivo: los grupos más ceñidos al modelo evangélico-sororal propio de los inicios de la centuria fueron dando paso a realidades de progresiva diferenciación interna aun cuando mantuviesen la denominación sororal y algunas formas organizativas inscritas en ella. Pero también se perfila la incidencia

\footnotetext{
${ }^{36}$ Así las tres hermanas Armenta, Isabel, Urraca y Beatriz: cada una propietaria de su parte de la herencia familiar, pusieron sus bienes en común y actuaron juntas y en términos de igualdad en todos sus negocios; en sus testamentos entregaron a sus hermanas su tercera parte de todo, pero en usufructo vitalicio porque los herederos eran los hermanos. AHPCProt, Oficio 14, leg. 6, cuad. 1, f. 40v; leg. 22, cuad. 2, ff. 9v-10r; Oficio 18, leg. 5, f. 135r; leg. 2, ff. 455r-457r y 544r-546v; RAH, ms. 9/5436, f. 669r-v.

${ }^{37}$ Prueba de esta realidad de acompañamiento sería la frecuencia con que la refleja la forma de nombrar y distinguir a las comunidades: por ejemplo, el beaterio del jurado Nicolás Rodríguez era denominado también de "Isabel Rodríguez la beata y sus compañeras". Las Armenta compraban, vendían y arrendaban inmuebles y raíces sin mencionar a sus compañeras, presentándose como "hermanas y religiosas". AHPCProt, Oficio 14, leg. 5, cuad. 7, f. 25r-v; leg. 22, cuad. 2, ff. 9v-10r.

${ }^{38}$ AHPCProt, Oficio 14, leg. 6, cuad. 1, f. 40v; leg. 15, cuad. 10, ff. 120r-122r; Oficio 18, leg. 2, ff. 455r-457r y 544r-546v; RAH, ms. 9/5436, f. 669r-v.

${ }^{39}$ AHPCProt, Oficio 14, leg. 6, cuad. 1, f. 40v; RAH, ms. 9/5436, f. 669r-v.
} 
espiritual: las formas más jerárquicas se correspondieron con la adscripción a espiritualidades institucionalizadas como la jerónima, en fase de consolidación cuando surgieron los beaterios identificados con ella.

Los vínculos que trababan esta realidad interna fueron de amor, acompañamiento, caridad y servicio, marcados por el común peso específico de la reciprocidad. Sin negar la posible variedad de situaciones favorecida por la flexible condición beata, su personalismo económico, sumado al compromiso religioso-regeneracionista y a un concepto comunitario evangélico sustentado en el amor y la paz, condujeron a fórmulas de apoyo material interno fundadas en nociones de solidaridad-caridad. Fue así en el hecho importante de que las beatas propietarias mantuviesen con sus bienes a otras menos favorecidas, acogiesen y educasen niñas pobres o aseguraran la supervivencia de las comunidades ${ }^{40}$. El amor se entendió en una parte importante, pues, como caridad y fundamento de comunidad, pero igualmente se sustentó sobre los lazos consanguíneos, tan importantes en este tipo beato, y sobre el acompañamiento.

Este último estuvo trabado con relaciones de muy distinto signo y sin duda debió gozar de gran peso específico la amistad; también fue muy notoria la dimensión de servicio. En general, el componente doméstico fue uno de los aspectos más característicos. No dejaba de ser lógico dado el emplazamiento beato en la vivienda particular, donde, además de poder seguir efectuándose contratos de servicio ${ }^{41} \mathrm{o}$ conservarse a los sirvientes de la familia ${ }^{42}$, el vínculo con y entre beatas pudo entenderse en esta dimensión. Se desvelan distintos intereses y fenomenologías. Fue muy estrecha la conexión entre la dedicación beata y los círculos femeninos de servicio doméstico, que constituyeron posibles ámbitos de integración religiosa femenina, de servicio-acompañamiento de beatas individuales o de comunidades, o que se integraron en éstas. Tales vínculos constituyeron un criterio organizativo comunitario con lecturas originales que pudieron fundarse en relaciones afectivas y magisteriales. Las mujeres con dedicación religiosa individual, especialmente las nobles, mantenían su grupo femenino de servicio y acompañamiento en su nueva singladura; aun cuando sus componentes no abrazasen esta forma de vida, sin duda la compartían en aspectos importantes dados los estrechos lazos personales que solía entrañar el vínculo de servicio en las sociedades tardomedievales ${ }^{43}$ y concretamente en los espacios feme$\operatorname{ninos}^{44}$. Tal vínculo doméstico se dio también en sentido contrario, de forma que las beatas individuales pudieron ser quienes sirviesen como criadas y acompañantes de mujeres laicas. Rasgos reveladores de la existencia de circuitos femeninos de acompañamiento y servicio que contribuían a sustentar y reforzar las dedicaciones religiosas independientes. Mas, por otra parte, aunque las noticias sean menos numerosas, las criadas también pudieron abrazar la vida religiosa e integrarse en las comunidades beatas. Estas características hacen de muchos beaterios la plasmación religiosa del

40 Así pudo Elvira Alfonso de la Cruz hacerse cargo del beaterio de Santa Marina tras la muerte de Catalina González y evitar que las casas residenciales pasasen al convento de Guadalupe, con lo que se habría dado fin a la comunidad. RAH, 9/5436, ff. 657r-663r.

${ }^{41}$ AHPCProt, Oficio 14, leg. 3, cuad. 2, f. 139v; leg. 7, cuad. 12, f. 155v; leg. 3, cuad. 2, f. [296v], f. 139v; leg. 7, cuad. 12, f. 155v; leg. 14, cuad. 1, f. 2r-v.

${ }^{42}$ Tanto criadas como criados, por necesidades laborales o fruto del afecto y la gratitud. En el beaterio de Armenta residían criados de los padres de las hermanas propietarias -AHPCProt, Oficio 18, leg. 2, ff. 544r-546v-. También se documentan criadas particulares de las beatas así como esclavas y, en menor número, esclavos. AHPCProt, Oficio 14, leg. 23, cuad. 14, f. 3r-v; leg. 26, cuad. 15, f. $15 \mathrm{r}-\mathrm{v}$; leg. 24, cuad. 7, f. 13v; leg. 8, cuad. 4, ff. 4r-6v; Oficio 25, leg. 3, ff. 52r-53r.

${ }^{43}$ M. Cabrera, Nobleza, pp. 381-383.

${ }^{44}$ AHPCProt, Oficio 14, leg. 13, cuad. 4, ff. 4r-6v. 
espacio doméstico. Junto a todos estos elementos, sin duda se dio también un reclutamiento indiscriminado, impulsado por el factor vocacional entre otros, pero que en los beaterios familiares perfila un sector comunitario diferenciado cuya situación en la vida cotidiana no es posible definir ${ }^{45}$.

A la hermana mayor competían las funciones directivas, espirituales y de gobierno interno. La cuestión radica en conocer sus contenidos y el sentido de su autoridad. Entre las beguinas de los Países Bajos, las denominadas "martas" o "maestras" ejercían roles ministeriales con sus religiosas al prepararlas para la confesión y darles permiso para ir a la iglesia, escuchar las predicaciones, confesarse y recibir la comunión ${ }^{46}$. Acaso estas últimas actividades fuesen atribuciones de las hermanas mayores al carecer casi todos los beaterios de espacio litúrgico propio y servirse de la iglesia parroquial. En los beaterios de jerónimas, que sí poseían capilla, esta autonomía de la directora del grupo pudo estar mediatizada por los religiosos de la orden, sobre lo que no hay noticias. Por lo demás, tuvo que haber diversidad de situaciones en el grado de individualismo o coparticipación en el ejercicio del gobierno interno según los niveles de jerarquización comunitaria. Nada se puede afirmar sobre la actuación de las hermanas mayores en los beaterios coparticipativos aunque se supongan formas de gobierno fundadas en el acuerdo, tal y como sucedía en otros grupos evangélicos ${ }^{47}$. Los grados de control aumentaban y, por consiguiente, también la limitación de capacidades comunitarias, en función de la distribución de la propiedad. En el extremo, en algunas de las comunidades donde la hermana mayor era además la propietaria de las casas residenciales se dieron casos de altos niveles de jerarquización: sucedió especialmente con los beaterios de espiritualidad jerónima surgidos sin afán de perdurabilidad ${ }^{48}$.

Probablemente la hermandad no se correspondiese con un sentido pleno de comunidad-sororidad en un sector importante de beaterios o, al menos, en un segundo momento cronológico, tras el que parece haber sido mayor igualitarismo inicial. Sin embargo, aunque los grupos se ajustasen en parte a la jerarquización social, el concepto de hermandad pudo actuar como matizador de jerarquías internas y aglutinante de mujeres de niveles económicos y procedencias sociales diversos que conformaban las comunidades como componentes de plena dignidad; desde este punto de vista, el beaterio constituyó una realidad organizativa novedosa que reflejó pero a la vez matizó las divisiones sociales imperantes. Por otra parte, se trató de comunidades femeninas con una opción espiritual muy definida y amplias cotas de autonomía organizativa, lo que sin duda redundó en beneficio de esa matización de las jerarquías sociológicas, al menos en relación con las estructuras del mundo circundante.

45 Así Marina, beata "que vive con las beatas religiosas de Armenta". AHPCProt, Oficio 14, leg. 33 , cuad. 19 , ff. $35 \mathrm{v}-41 \mathrm{v}$.

${ }^{46}$ S. Gieben, Vita comunitaria, p. 151.

${ }^{47}$ También masculinos. M.D. Chenu, El despertar. Una lectura en clave femenina, en A. Muñoz, Subjetividad, pp. 39-60.

${ }^{48}$ Isabel Rodríguez legaba de forma condicionada las casas a sus compañeras atendiendo a su observancia de la clausura y las excluía del control organizativo al hacer recaer sobre el prior de San Jerónimo de Valparaíso las principales funciones de la hermana mayor, el correcto funcionamiento interno y la admisión de nuevas hermanas. Otro tanto señalaría el testamento de Catalina González, que ni siquiera legaba las casas a sus compañeras, sino al convento de Guadalupe. RAH, ms. 9/5436, f. 669r-v; AHPCProt, Oficio 14, leg. 6, cuad. 1, f. 40v. 


\subsection{Un proyecto evangélico de relación entre los sexos}

La vida beata se inscribió también en un proyecto evangélico de relación entre los sexos. En el contexto reformista, algunas mujeres de vida religiosa pudieron desear compartir proyectos, espacios y formas de vida con los hombres. Este deseo, propiamente cristiano en su raíz dado el carácter comunitario de esta fe y su reconocimiento teológico de igualdad de las almas en el orden de redención ${ }^{49}$, se entiende también como fruto del ideal evangélico, un proyecto de renovación socioeclesial que pretendía recrear la comunidad apostólica nacida en torno a Jesús -en la que se integraron mujeres y hombres en concepto de discípulas $/ \mathrm{os}^{50}$. En sintonía con ello, uno de los rasgos definitorios de dicho proyecto fue la reformulación de los conceptos de autoridad y relación dando origen a nuevas eclesiologías en clave fraterna y amoro$\mathrm{sa}^{51}$. Este ideal de comunión y fraternidad entre los sexos, ¿se planteó en términos de igualdad en sintonía con algunos de los nuevos ideales humanistas contemporáneos ?52

En líneas generales, las beatas ofrecieron dos planteamientos: la plena autonomía respecto a los varones religiosos, sus grupos y órdenes, o bien el deseo de compartir su misma inspiración carismática, lo que comportó diferentes proyectos relacionales entre los $\operatorname{sexos}^{53}$. La fraternidad entre los sexos parece haberse buscado en los orígenes del movimiento comunitario beato cordobés. Los indicios permiten conjeturar la existencia de, al menos, un grupo con importantes intereses compartidos, el de las beatas "bizocas" y los ermitaños de la Albaida, asentados en la sierra próxima a la urbe. Es difícil determinar si configuraron una fraternidad evangélica propiamente dicha y con un plan de acción conjunta, aunque resultan evidentes la sintonía espiritual, la comunicación fluida y la asistencia mutua. También es difícil caracterizar sus vínculos. Ambos grupos partían de una situación de igualdad en el aspecto clave de su condición laica y el reconocimiento de su capacidad de reforma, sustentada en la noción de igualdad de las almas y muy probablemente también de los sexos en cuestión de dignidad espiritual; compartían además una misma inspiración carismática que pudo comportar actividades comunes -acaso en el terreno de la oración-y sin duda garantizó amplias cotas de libertad relacional. No es posible determinar si sus fundamentos eran o no el magisterio y la autoridad carismática masculinos: la tradición achaca a los ermitaños la difusión de las nuevas corrientes de espiritualidad, de influjo italiano, que sustentaron su proyecto religioso y, sin duda también -como su propia nomenclatura indica- el de las "bizocas", pero esto no impide otorgar responsabilidad de autoría a unas beatas para quienes la peregrinación fue actividad frecuente ${ }^{54}$.

La fraternidad espiritual y dedicacional sólo debió ser posible en estos grupos laicos. Partieron de un afán de regeneración por el ejemplo y por encima de la ley que permitió tramar las relaciones fuera de las estructuras de jerarquía y sin que hubiese lugar para la subordinación femenina, sino para la igualdad en inspiraciones

${ }^{49}$ E. McLaughlin, Equality, pp. 213-266.

${ }^{50} \mathrm{El}$ "sineisactismo" o relaciones de igualdad espiritual entre los sexos propias del cristianismo primitivo, en J.A. McNamara, Hermanas.

${ }^{51}$ Los nuevos conceptos de autoridad, en C. Bynum, Jesus, pp. 110-169.

52 Sobre los planteamientos relacionales entre los sexos: M.M. Rivera, La diferencia; idem, La política, pp. 139-204.

${ }^{53}$ A diferencia de lo poco significativas que habrían sido estas relaciones entre las primeras beguinas. M.M. Rivera, La diferencia, p. 96.

${ }^{54}$ En Córdoba se documenta a María Sánchez “de Gerosalem” en 1363 -ACC, caja T, núm. 204; CMC, 1363. Sobre la habitual actividad de peregrinación de las beatas, E. Botinas, J. Cabaleiro, M.A. Durán, Les beguines, pp. 61-63. 
y objetivos, aunque no en las formas de actuación más características. ¿Por qué las diferencias? Podían justificarlas los tabúes contrarios a un eremitismo femenino en el fragor de la montaña o el desierto; también la superioridad numérica del movimiento femenino respecto al masculino o las razones demográficas que afectaron específicamente a las mujeres. Asimismo, debieron obedecer a planteamientos políticos propios de mujeres que, a diferencia de sus compañeros espirituales, quisieron incidir directa y plenamente sobre la vida urbana. En cualquier caso, se percibe una conciencia sexuada de las tareas a desarrollar que acaso esté desvelando una posible manifestación de la teoría de la complementariedad de los sexos tal y como la definieron algunas teólogas medievales ${ }^{55}$.

El punto de no retorno fue la clericalización, asociada a la institucionalización, la definición estructural-canónica y la elevación social, procesos de desarrollo acelerado que introdujeron relaciones de asimetría fundadas en la superioridad masculina dada la imposibilidad de que las mujeres fuesen ordenadas, lo que imponía jerarquías en dignidad sacra habitualmente traducidas en diferencias sociales, y la necesaria asistencia litúrgica y espiritual que precisaban. Estos cambios tendían por otra parte a identificar el celibato a que obligaba el estatus sacro masculino con otra necesidad, el encerramiento femenino, lo que a su vez pudo derivar en posturas de prevención hacia las mujeres, el desarrollo de la misoginia y tendencias institucionalizadoras.

Pese a la jerarquía inherente a esta situación, la clericalización de ellos no obstaculizó el afán femenino por mantener trayectorias paralelas y compartir identidades espirituales y proyectos comunes de reforma, en algún caso incluso a costa de asumir rasgos de mayor institucionalización. En esta línea política se situaría buena parte del fenómeno beato comunitario en su segunda fase. Las actitudes masculinas hacia las religiosas fueron de variado contenido y cronología. Interesa la Orden de San Jerónimo, grupo evangélico institucionalizado que, en principio, no quiso admitir monjas en su seno y tuvo una ambivalente relación con los beaterios de su espiritualidad, aspectos indicativos de la falta de un proyecto pleno de fraternidad que incluyese a las mujeres. Es dudosa su responsabilidad última en el origen de estos beaterios en Córdoba, aunque coincidió con el momento de su máxima irradiación. Debieron coexistir dos situaciones: una acción pastoral de animación femenina conscientemente ejercida por los religiosos al servicio probable de sus intereses de presencia urbana, así como el deseo femenino de participación en la espiritualidad jerónima. Los vínculos resultantes no son de fácil determinación: estos beaterios contaban con capilla, lo que acaso favoreciese la actividad litúrgica y magisterial masculina; sólo en fecha tardía y de forma selectiva se documentan lazos de sometimiento a las autoridades jerónimas en observancia religiosa y gobierno interno, pero sin haberse dado una incorporación formal en sus estructuras; al tiempo, otros espacios eran autónomos o mantenían otros lazos espirituales y económicos con religiosos fuera de la urbe ${ }^{56}$.

En las beatas no vinculadas a movimientos u órdenes religiosos, la inspiración evangélico-reformista pudo incidir en sus contactos con el clero, si bien en todo momento en una dimensión de autonomía por no buscar compartir espacios con los varones. Se documentan lazos con el clero diocesano referidos al ámbito de la asistencia litúrgico-sacramental y a la dirección espiritual masculina, sobre todo con los sacerdotes de las parroquias de residencia aunque también canónigos en los que

${ }^{55}$ La que defiende que los sexos son iguales aunque sustancialmente diferentes. M.M. Rivera, La política.

${ }^{56}$ RAH, ms. 9/5436, f. 669r-v; AHPCProt, Oficio 14, leg. 6, cuad. 1, f. 40v. 
se perfilan como lazos de autoridad masculina y de amistad o sintonía afectiva ${ }^{57}$. Y se detectan indicios de una posible actividad pastoral dirigida al colectivo beato, sobre todo entre el clero diocesano en los orígenes del fenómeno y, con posterioridad, entre los religiosos ${ }^{58}$.

\subsection{En pro del bienestar social: caridad, trabajo y oración}

El movimiento religioso planteó una cura animarum femenina activa no siempre fácil de precisar aunque venga probada por la frecuencia con que las beatas eran recompensadas por sus "buenos servicios" o "buenas obras". Estas actividades, que en algún caso se convirtieron en trabajo remunerado, contribuyeron a crear redes de redistribución económica propias. La escasez informativa dificulta valorar su verdadero alcance y sólo permite algunas reflexiones indicativas.

Una parte sustancial de la actividad de las beatas estuvo al servicio del bienestar social, no tanto de la productividad o la reproducción aunque éstas también se diesen. Su mayor peso específico se alcanzó mediante su inserción en las redes asistenciales y de caridad, pero también con la forja de sus propios entramados relacionales. Destacó la actividad asistencial en las instituciones creadas a tal fin, los hospitales: es indicativa la coincidencia entre el área de máxima densidad beata y hospitalaria, la Ajerquía ${ }^{59}$; allí debieron ejercer un tipo de actividad itinerante que compaginaban con la asistencia en sus residencias, convertidas en lugar de acogida de pobres, marginados y enfermos. Partían de un fundamento teológico: la espiritualidad evangélica hallaba en los pobres y enfermos al Cristo sufriente al que atender ${ }^{60}$. Por otra parte, como hemos visto, los vínculos entre mujeres pudieron conllevar formas alternativas de asistencia caritativa ${ }^{61}$.

En la misma línea asistencial, su labor de consuelo y acompañamiento espiritual, acaso especialmente en el momento del fallecimiento y en lo relativo al mismo -amortajamiento, acompañamiento al cadáver y a la familia o primeras oraciones por difuntos-. Igualmente su trabajo doméstico, que implicaba las habituales tareas de servicio y, sobre todo, de acompañamiento a otras mujeres no necesariamente religiosas. El panorama, muy diverso, comprendía situaciones que hallaban en este trabajo remunerado un medio necesario de manutención, pero también otra forma de caridad, incluso de pastoral y, en cualquier caso, de manifestación de relaciones de amor entre

\footnotetext{
${ }^{57}$ Los sacerdotes podían ejercer el papel de albaceas de las beatas, como el clérigo rector de Santiago por disposición de la beata María González, vecina en dicha collación, que además encargaba el rezo de salmos y varias misas por un racionero de la catedral. Sin olvidar los vínculos devotos y litúrgicos documentados entre canónigos y beatas individuales desde el último tercio del XIV. ASC, cajón $10^{\circ}$, pieza $1^{\mathrm{a}}$, instrumento $22^{\circ}$; ACC, caja T, núm. 204; CMC, 1363.

${ }^{58}$ La beata Catalina López la Serrana tenía como confesor a fray Juan de Benavente, de Madre de Dios, que también confesaba a la beata María González. Algo similar sucedió con el vicario de Santa Inés, confesor de beatas y albacea de vecinas de la collación. AHPCProt, Oficio 14, leg. 22, cuad. 7, ff. 1r-5v; cuad. 4 (1488), ff. 28r-30r; leg. 23, cuad. 6, ff. 2r-6r; ASC, cajón 10º pieza 1ª , instrumento $22^{\circ}$.

${ }^{59}$ El ermitaño Martín Gómez fue atendido hasta la muerte por las beatas "bizocas" en su residencia. El caso posterior de la terciaria doña Leonor Venegas, que cobijaba y sustentaba en su casa a cuatro pobres además de visitar de forma itinerante los hospitales, debió tener precedentes entre las beatas no regladas. J. López, Tercera parte, pp. 229, 232.

${ }^{60}$ Casos posteriores, en ibidem, p. 232.

${ }^{61}$ Lucía Rodríguez legaba 3.000 mrs. para ayudar al casamiento de la huérfana Catalina, "a la que conoce la beata Beatriz Fernández", que debía mediar en su entrega. AHPCProt, Oficio 18, leg. 5, ff. $180 \mathrm{v}-181 \mathrm{v}$.
} 
mujeres, pues hubo beatas propietarias que residieron en casas ajenas como acompañantes de sus dueñas y sólo las abandonaron tras su muerte ${ }^{62}$. Otras tareas al servicio de las familias y la distribución de sus bienes como tutoras o albaceas testamentarias constituían puntos de encuentro entre el servicio social general y los intereses de reproducción familiar. No eran labores nítidamente definidas en el mercado de trabajo, pero las religiosas las asumían como funciones inherentes a su programa carismático apostólico de servicio social caritativo ${ }^{63}$. También desarrollaron una importante actividad educativa completada por una función de crianza que pudo atender a los dos sexos pero que ofrece una notoria dimensión femenina y asistencial al beneficiar a niñas pobres y huérfanas que hallaban ámbitos de acogida y promoción social. No se documenta tanto como actividad externa desarrollada en escuelas propiamente dichas, las denominadas "amigas" 64 , sino en una dimensión de carácter privado y privativo ${ }^{65}$.

La actividad con mayor proyección económica en su medio social, la mediación salvífica por vía de oración -que en su forma más habitual respondía a encargos de rezar los salmos-, se halló también a medio camino entre la asistencia social, la caridad y el trabajo remunerado. Fue una forma de asistencia a las almas, implicaba un acompañamiento en la oración y una sanación de los pecados con fruto salvífico. La caridad espiritual hacia el prójimo se hallaba trabada con el trabajo pues esta actividad se pagaba con dinero y da la impresión de que tenía un precio preestablecido ${ }^{66}$.

Las beatas ejercieron un trabajo productivo en el sector secundario, en concreto en el ámbito textil, una actividad laboral tradicionalmente asociada a las mujeres y de gran peso en Córdoba ${ }^{67}$, aunque no queda claro el límite entre la actividad profesional y la religiosa. Hubo beatas artesanas de la industria textil y de confección que con su dedicación religiosa parecen haber obtenido autorización social para llevar adelante una vida y actividad laboral independientes, una dedicación sin duda más extendida de lo que desvelan las fuentes dada la importante producción desarrollada en todo el obispado ${ }^{68}$ y que, como en otros ámbitos europeos, debió ejercerse al margen de los gremios. Además de mantenerse con el fruto de su trabajo, probablemente destinaron parte del mismo a las tareas de asistencia y caridad ${ }^{69}$. De una forma u otra, se aprecia que la dedicación religiosa femenina laica potenció la producción artesanal cordobesa en el sector textil, situación que pudo estar favorecida por el hecho de que a lo largo del siglo XV el sector no contase todavía con estructuras gremiales completas, así como por una posible mayor intervención femenina en el obraje de paños -hilado, cardado y tejido-, de carácter disperso y menos especializado en la ciudad ${ }^{70}$.

${ }^{62}$ ASC, cajón $10^{\mathrm{a}}$, pieza $1^{\mathrm{a}}$, instrumento $22^{\circ}$; cajón $7^{\circ}$, pieza $4^{\mathrm{a}}$, instrumento $10^{\circ}$.

${ }^{63}$ La beata Inés González, acompañante de María González, fue su albacea con Juan Sánchez, clérigo rector de Santiago. ASC, cajón $10^{\mathrm{a}}$, pieza $1^{\mathrm{a}}$, instrumento $22^{\circ}$.

${ }^{64}$ Sobre la actividad educativa beata: P.M. Cátedra, A. Rojo, Bibliotecas, pp. 50-51, nota 29.

65 Teresa Muñiz había criado a la niña Inés; le tenía "mucho amor" a ella y a su sobrina mayor y posible sucesora, Leonor; si Inés quisiera quedarse en el beaterio, mandaba a sus sobrinas y a la madre "que la traten muy bien y con mucho amor como yo lo he fecho y lo hago y le provean de todo lo necesario como a cada una de las otras de la casa y compañía". AHPCProt, Oficio 21, leg. 14, ff. 410r-419r.

${ }^{66} \mathrm{RAH}, 9 / 5434$, ff. 747r-743v.

${ }^{67}$ J.I. Fortea, Córdoba, p. 229. Es conocida la asociación de esta actividad con las mujeres como "trabajo emblemático": M.G. Muzzarelli, Un'introduzione, p. 16; D. Herlihy, Opera, pp. 69-70.

68 J.I. Fortea, Córdoba, pp. 267 y ss.

${ }^{69}$ Leonor Venegas se dedicaba a hilar todos los días dos onzas de algodón con las que sustentaba a los pobres enfermos que albergaba en su casa. J. López, Tercera parte.

${ }^{70}$ J.I. Fortea, Córdoba, pp. 266-267 y 271-272. 
Salvo en esta última dimensión productiva, las beatas figuran insertas en los circuitos materiales de la caridad como receptoras y emisoras. Participaron y se beneficiaron del sistema asistencial urbano establecido y, al tiempo, crearon sus propias redes de ayuda y solidaridad en el contexto de la privacidad, la casa particular -tuviese connotación religiosa o no-, un ámbito doméstico al que con su trabajo otorgaron una nueva dimensión carismática y evangélica. Además, las comunidades forjaron entramados de ayuda interna: su concepto de solidaridad-caridad no sólo implicaba la recepción de mujeres pobres que se beneficiaban del patrimonio de las ricas al convivir con ellas o el hecho de que las religiosas se favoreciesen materialmente entre sí con legados personalizados ${ }^{71}$, sino también que las más pudientes ayudasen con sus bienes a la comunidad en sus necesidades hasta el punto de determinar su supervivencia.

\subsection{La vecindad como vínculo articulador del movimiento religioso femenino}

Las beatas no regladas ofrecen una primera imagen de gran desarticulación general. Las comunidades no constituyeron realidades supracomunitarias que plasmasen a gran escala su ideal evangélico fraterno ni hay indicios de que pudieran haber deseado constituirlas. Este rasgo característico era coherente con el planteamiento carismático de una forma de vida marcada por el peso del elemento espontáneo e individual y su evidente tendencia al particularismo interno, así como sus presupuestos espirituales de libertad, no estructurales por definición. Se intuye una opción deliberada por la no-estructura y la simplicidad como registro evangélico, a lo que debió sumarse la necesidad de ofrecer un modelo cristiano alternativo al eclesiástico canónico, asfixiado por la estructura y la jerarquía. Pero es preciso considerar además otro afán compartido: el deseo de identificarse con, e incluso, en cierto sentido, de diluirse en, la comunidad cívica urbana, así como el importante peso específico de los vínculos de vecindad.

Las beatas se identificaron con el común de la gente y saldaron algunas de sus necesidades sin formar cuerpo sacro aparte, con una preferencia muy marcada por la sociedad laica. La conexión con la ciudad entendida como comunidad cívica y espacio de vida fue una de las principales pautas articuladoras del movimiento religioso laico. Más que estructuras organizativas, se detectan pautas de identificación urbanística y redes relacionales tramadas en torno suyo. El vínculo topográfico fue instrumento aglutinante $y$, en parte, definidor de identidades. Las beatas pudieron ceñirse a algunos elementos urbanísticos del entramado ciudadano, con los que se identificaron y a los que otorgaron una dimensión trascendente. Sobre todo las comunidades se concentraron en un sector urbanístico concreto, la Ajerquía, y en collaciones con importante presencia hospitalaria o ubicadas en el sector fronterizo de la urbe. La cercanía de muchos de los espacios religiosos invita a pensar que, si no hubo una articulación formal supracomunitaria, se dieron otras conexiones favorecidas por una identificación urbanística que incluso potenciaría vínculos entre distintas dedicaciones. Conexiones reveladoras del posible efecto impulsor ejercido por los espacios de mujeres religiosas entre sí y por el cual se generasen posibles líneas de atracción y formas de organización en esquemas topográficos propios que rebasarían el concepto de agrupación de una tipología religiosa concreta o congregación y que podemos caracterizar como espacios religiosos en relación.

Se perciben interrelaciones entre emparedadas, beaterios y beatas individuales en las collaciones de mayor densidad religiosa laica y en el origen de sus

${ }^{71}$ AHPC, Clero, libro 174. 
espacios, indicio revelador del peso específico de los lazos de vecindad. Así en San Llorente entre las beatas del Cañuelo y las emparedadas ${ }^{72}$. En Santa Marina, donde las religiosas siguieron una distribución ordenada configurando un eje norte-sur compuesto por las de la calle del Zarco, en dirección opuesta y complementaria a las beatas de Santa Marina con, entre medias, las emparedadas de la iglesia parroquial. En la Magdalena, tendente a la concentración de un núcleo de mujeres religiosas bastante próximo y del que formaban parte las beatas de Armenta, las beatas "bizocas" y la iglesia parroquial donde radicaba el emparedamiento con beatas individuales en las cercanías y un microbeaterio cerca del pozo $^{73}$, algo más lejos pero en eje con los beaterios y la parroquia. Estas redes topográficas parecen mostrar que, si bien no se trataba de grupos formalmente estructurados, ello no significaba que no ofreciesen una imagen de coherencia socioespiritual y relacional fundada en una inspiración reformista-evangélica compartida y un objetivo común de acción apostólica, mutua ayuda, intercambio de experiencias y, acaso, acciones sociales y pastorales conjuntas en un espacio urbanístico concreto a modo de marco de enraizamiento, la collación como base y el sector más amplio de la Ajerquía como marco de operaciones preferente, identificación urbanística que denota el peso de la noción de vecindad.

Además de la ciudad en su doble dimensión de comunidad cívica y realidad topográfica y de la propia noción de vecindad, de compartir un mismo espacio urbano, ofrecen otra importante pauta de articulación del movimiento religioso femenino los vínculos personales: de afecto, comunicación, ayuda mutua e identificación. Pudieron corresponderse con la concordancia urbana y topográfica, incluso con la propia filiación espiritual, pero también con diferentes dedicaciones religiosas y rebasando las delimitaciones urbanísticas.

Las interrelaciones entre religiosas en sectores urbanísticos concretos pudieron obedecer también al impulso ejercido por unos espacios de vida espiritual sobre otros, acaso en un afán de potenciar los carismas propios en dichos sectores urbanos, con los que se identificaban, y, por consiguiente, la propia noción de vecindad. No es fácil documentar estos vínculos. De forma llamativa, se perciben entre beatas y determinadas instituciones monásticas femeninas: hubo redes de beatas en torno a monasterios como el cisterciense de Santa María de las Dueñas y, ya con posterioridad, el clariano de Santa Inés. El primero estuvo muy conectado con parte del fenómeno beato inicial, acaso como impulsor suyo; el gran peso específico de su irradiación sociológica popular podría indicar el ejercicio de una acción pastoral consciente en su calidad de cenobio de obediencia episcopal y por parte del clero diocesano, catedralicio y parroquial, que acaso repercutiese. La espiritualidad cisterciense, tan del gusto de las mujeres, que en siglos anteriores habían protagonizado en otros ámbitos europeos fenómenos masivos de adhesión, laica y monástica, pudo constituir un factor de identificación. Todo hace sospechar que Santa María de las Dueñas constituyó un epicentro de animación beata especialmente notorio en su collación residencial u otras de la Villa ${ }^{74}$. Las beatas involucradas, artesanas en la primera mitad del siglo XV, parecen haber sido individuales. En Santa Inés la cercanía espacial fue más notoria, pues cerca del monasterio se ubicaban beaterios como el de Armenta y beatas individuales que compartían con las monjas su espiritualidad franciscana. Si el origen del beaterio no pudo haber sido impulsado por el cenobio, acaso las dedicaciones individuales sí

72 ACC, caja B, VI.589; CMC, 1490-2.

${ }^{73}$ AHPCProt, Oficio 14, leg. 33, cuad. 19, ff. 35v-41r; leg. 4, cuad. 6, ff. 41r-43v. La configuración urbanística de esta collación, en J.M. Escobar, Córdoba, p. 267.

74 AHPCProt, Oficio 14, leg. 19, cuad. 1, ff. 21r-24v; leg. 15, cuad. 2, ff. 9v-10v; leg. 13, cuad. 18, f. 10r-v; AHPC, Clero, pergs., carp. 39, núm. 6; ACC, caja D, núm. 525; CMC, 1441. 
hubiesen obedecido en parte a su posible irradiación pastoral, como prueba el hecho de que su vicario fuese confesor de beatas residentes en la Ajerquía ${ }^{75}$.

Estos vínculos parecen haberse fundado en afinidades espirituales y en la prestación de servicios donde cabrían formas de asistencia mutua incluyendo la acogida residencial que se documenta en Santa María de las Dueñas ${ }^{76}$ o el apoyo económico, sobre todo por parte de las beatas hacia las monjas. Se deseaba asegurar su perpetuación en el tiempo solicitando las oraciones de éstas como mediación para la otra vida o bien otorgando donaciones con reserva de usufructo con las que afianzar la relación en el plano económico, hecho muy llamativo dada la drástica reducción de esta fórmula de traspaso de la propiedad. En algún caso se desvela el peso específico que el apoyo económico beato tuvo para sacar adelante proyectos monásticos reformistas y novedosos nacidos del impulso femenino libre. Así, el espectro relacional de Santa Inés rebasó la línea residencial inmediata para incluir también a beatas de la collación originaria del primitivo beaterio que le dio origen, San Llorente. Unas y otras se caracterizaron por prestar su ayuda material a las monjas ${ }^{77}$. En este sentido, es importante considerar el peso específico de las donaciones de inmuebles que las beatas otorgaron a estos monasterios y, sobre todo, su carácter de hecho excepcional al ser mayoritariamente no litúrgicas en un contexto en que esta fórmula de traspaso de la propiedad se hallaba en práctico desuso, lo que contribuye a resaltar la fuerza y el carácter especial del vínculo beatas-monjas. Sin olvidar los servicios prestados por las monjas, las beatas las beneficiaron con sus bienes y ejercieron una suerte de papel de animadoras devocionales de las monjas en lo que acaso constituiría un ejercicio pastoral en dirección contraria a la señalada líneas atrás, animación devota plasmada en el legado de libros y objetos cultuales. Santa María de las Dueñas fue el único monasterio que ha dejado huella de vínculos devoto-culturales y circuitos de intercambio de libros con beatas, que en ocasiones justificaban sus legados por el buen debdo que tenían con las monjas. Forma o vehículo de relación, el libro se destinaba a la comunidad o monjas concretas, indicio de relaciones personales. Por su parte, Santa Inés recibió objetos cultuales que reforzaban su identidad espiritual, como un retablo con la historia de su santa titular ${ }^{78}$.

Son, todas ellas, manifestaciones del gran peso de la ayuda mutua y los intercambios entre beatas y monjas adheridas a espiritualidades y planteamientos de reforma. Un marco de colaboración que rebasaba la tipología estricta de las formas de vida por sintonizar con proyectos comunes y necesidades de supervivencia. Y que, si bien se sustentaba en una parte importante en lazos de vecindad y cercanía física, podía configurar áreas religiosas y devocionales supra-parroquiales aunque no supraurbanísticas. Así la zona sur de San Llorente en conexión con el norte-centro de la Magdalena en torno a Santa Inés, que actuaría como núcleo aglutinante, o diversas collaciones de la Villa en torno a Dueñas, posibles indicadores de que, cuando se incluía en la red relacional un monasterio, se organizaron unidades de encuadramiento humano urbano supraparroquial en las que se aglutinaban diferentes dedicaciones religiosas y que se fundaron en el mutuo servicio, el apoyo material y la mediación fe-

75 AHPCProt, Oficio 18, leg. 2, ff. 544r-546v; Oficio 14, leg. 22, cuad. 4 (1488), ff. 28r-30r; leg. 22, cuad. 2 (1488), ff. 26r-27v; ASC, cajón $10^{\circ}$, pieza $1^{\mathrm{a}}$, instrumento $22^{\circ}$. núm. 6.

${ }^{76}$ La beata Juana Rodríguez era "habitante" en Dueñas en 1498. AHPC, Clero, pergs., carp. 39,

77 AHPCProt, Oficio 18, leg. 1, cuad. 7, f. 28v; cuad. 28, ff. 2v-3v; Oficio 14, leg. 13, cuad. 1; leg. 22, cuad. 7 , ff. 1r-5v.

${ }^{78}$ AHPCProt, Oficio 14, leg. 13, cuad. 1 (1477), ff. 12v-15r; leg. 22, cuad. 2 (1488), ff. 26r-27v; ACC, Obras pías, caja 902; CMC, 1472-2. 
menina. Sobre todo Santa Inés desvela la importancia de las solidaridades materiales de mujeres y la transmisión de bienes con que favorecían proyectos religiosos nuevos. Pero es cierto que no parecen haber rebasado su área urbanística de identificación, es decir, Ajerquía Santa Inés y Villa las Dueñas.

La inexistencia de una estructura reformista común, ¿ha de interpretarse como falta de un planteamiento coherente? Para responder, revisemos la dimensión política del reformismo femenino.

\section{REGENERACIÓN ECLESIAL Y SIGNIFICACIÓN TRASCENDENTE DE LA COMUNIDAD CÍVICA: EL PESO FEMENINO EN LA CIUDAD}

Los inicios de la forma de consagración beata obedecieron a un afán de renovación eclesial que no radicaba tanto en reformar cuanto en "re-generar" la Iglesia -entendida como la colectividad de los cristianos por encima de la institución jerárquica- en su sentido literal, volver a dar vida a una comunidad eclesial cuyas estructuras se hallaban desprestigiadas por los intereses de poder y hacerlo no sólo en un intento de vuelta a los orígenes y recuperación de su pureza, sino también, en buena medida, añadiendo novedades al proyecto cristiano o, quizá más bien, reinterpretándolo en una parte importante al desarrollar algunos de los nervios de fondo menos explicitados en siglos anteriores. En la dimensión más evidente, enfatizaba los contenidos evangélicos que el monacato femenino casi había olvidado. No podía ser mayor el contraste entre unas renovadoras formas de vida laica protagonizadas por los sectores no privilegiados y un monacato femenino aristocrático carente de propuestas reformistas, concretado en el monasterio de Santa Clara. Tal contraste debió ser conscientemente buscado, halló en la ciudad su mejor escenario de plasmación y perfila una de las tramas fundamentales de la dinámica del fenómeno beato no reglado.

Pero es importante insistir en que la propuesta de las beatas, más allá de un ideal de regeneración entendido como reforma, radicó en un verdadero proyecto de recreación ${ }^{79}$. Recreación de la vida religiosa femenina al ofrecer un modelo alternativo al monacato, muy marcado por el componente apostólico activo que las monjas no podían desarrollar por su definición contemplativo-claustral. La simbiosis accióncontemplación ofrecía en la propuesta beata amplios y libres campos de actuación ajenos al ámbito sacro oficial femenino; sólo en esta dimensión no reglada podían las mujeres integrarse en las corrientes de renovación apostólica activa. Incluso en las propuestas beatas recogidas, básicamente adscritas a la espiritualidad jerónima, el elemento de novedad siguió siendo notorio en la propuesta religiosa misma y por tratarse de una forma de vida que no se había concretado en la institución eclesial al carecer la orden de rama femenina canónica.

Pero, sobre todo, recreación que daba vida a una nueva eclesiología. La propuesta beata enfatizaba la capacidad de libre autorreforma y de significación eclesiológica personales como vía de mejora y santificación de la entera comunidad cristiana por encima de leyes, instituciones y estructuras. De lo cual se infería la posibilidad de dar origen a un cuerpo eclesial alternativo, desde la dignidad individual y laica enfatizada por la posibilidad de contacto directo con Dios y el reconocimiento de su capacidad sacra y mediadora, así como desde la marginalidad institucional -que no eclesial-, una Iglesia espiritual más allá de las estructuras oficiales. Cierto que las beatas compartieron estas propuestas, o algunas de ellas, con otras formas de vida como el emparedamiento u otros movimientos laicos, no siempre de clara ortodo-

${ }^{79}$ Han resaltado su carácter de novedad: G. Epiney-Burgard, E. Zum Brunn, Mujeres, pp. 17 y ss. 
$x{ }^{80}{ }^{80}$ que en algún caso desembocarían en el protestantismo. También con propuestas masculinas como el movimiento cordobés de ermitaños. Pero el fenómeno beato ofrece una marcada originalidad. Mostró una plasmación vital y una proyección eclesial diferentes a las emparedadas. A diferencia del coetáneo movimiento masculino, el femenino se caracterizó por su mayor peso cuantitativo, su pertinacia a-institucional y su vinculación con la ciudad. Porque ellos, aun manteniendo el contacto pastoral con la metrópoli, fundaron su propuesta reformista en la huida extramuros. Pero las beatas trabajaron por ser signos evangélicos visibles y forjaron un proyecto reformista inserto en el cuerpo urbano y a su servicio. Visibilidad e inserción extensivas al diseminarse por toda la ciudad.

Plan de recreación y propuesta original que muestran una acusada vertiente política todavía más notoria si se consideran el contexto histórico de origen y desarrollo de esta forma de vida y su especialización sociológica. El interés por proyectarse e incidir socialmente o, con más propiedad, eclesialmente, es consustancial al cristianismo. No de otro modo podría entenderse una propuesta renovadora en el seno de una religión comunitaria y universal por excelencia ${ }^{81}$. A través de la vida religiosa, ellas crearon proyectos y formas socioeclesiales alternativos: éste fue uno de los fundamentos de sus propuestas espirituales. Expondré dos principales claves articuladoras.

\subsection{Una sociedad femenina en el cuerpo urbano}

Las beatas propusieron espacios y fórmulas alternativos a las estructuras imperantes desde una conciencia sexuada que, además de buscar vías de existencia libre, muestra un afán de incidencia socioeclesial aportando al mundo capital simbólico femenino y logrando reconocerse y hacerse reconocer autoridad. Es conocido el intenso componente libre de una forma de vida que se concretó en espacios de independencia y autonomía vital respecto a la familia y las instituciones eclesiásticas. Aunque esta independencia vital ofrece trazas de notorio individualismo tanto si se trataba de dedicaciones comunitarias como si no, fue inseparable de los vínculos entre mujeres. Vínculos cuyo peso específico e intensidad fueron tan grandes que perfilan un fenómeno notoriamente sexuado y dan forma a una "sociedad de mujeres" con entidad propia dentro del entramado social general, casi autosuficiente aunque imbricada en la ciudad. La documentación refleja todo un universo de contactos entre mujeres y el ejercicio de una cura animarum con fuerte dimensión pastoral femenina; refleja también que una parte sustancial de la dedicación beata estuvo orientada a la mejora de las condiciones de vida de su sexo.

Es difícil valorar a partir de los datos disponibles el alcance de este fenómeno en su repercusión externa. Las referencias parecen remitir a acciones protagonizadas por religiosas que no vivían en comunidad, pues ésta no se menciona, si bien el individualismo beato acaso determinase que no se autonombrasen en relación al grupo como, en cambio, sí hacían las monjas. Fuera de un modo u otro, además de su labor al servicio comunitario, las beatas figuran como agentes individuales de una red de transmisión pastoral enteramente femenina y personalizada en una doble dimensión emisora-receptora. Formaron parte de este entramado al servicio de la difu-

${ }^{80} \mathrm{El}$ contexto general de formas de vida laica, en J.A. García de Cortázar, Cristianismo.

${ }^{81}$ La visión cristiana del cambio permanente y revolucionario en la Iglesia y en la sociedad, su raíz evangélica y su incidencia en el cambio de estructuras, en B. Bennassar, Contestación, pp. 78-103. En la misma línea, algunas teorías de Max Weber comentadas por C.A. Lynch, Individuals, pp. 5 y ss. 
sión espiritual las parientas y otras religiosas. Contribuyeron a propagar entre ellas la práctica de la oración individual, probablemente afectivo-meditativa-aunque no sólo o necesariamente- y una espiritualidad que, además de poder estar vinculada a alguna de las más importantes corrientes religiosas del momento como el franciscanismo y algunas de sus propuestas reformistas radicales de signo escatológico, ofrece componentes propios en la centralidad de las imágenes, así como en el peso específico de las figuras femeninas de devoción ${ }^{82}$. Actividad pastoral que seguía pautas y líneas de difusión propias, diferentes a las masculinas, y con especialización religiosa y sexuada.

Se entiende así la organización de redes de objetos cultuales y de libros devotos cuya lectura era necesaria para la oración personal: la beata Inés García de Requena legaba en su testamento de 1465 un libro de horas y el libro que dizen de Santo Francisco -probablemente el Floreto de San Francisco ${ }^{83}$, hecho indicativo de una inspiración espiritual en posible conexión con el franciscanismo radical- a una sobrina y una prima beata; y, en el de 1472 todos los retablos que tiene, además de figuras de la Virgen y Santa Águeda y un libro de horas a su sobrina más dos libros en papel, uno de San Fulgencio y otro de las Tribulaciones, a las monjas de las Dueñas. Aunque el segundo pudo tratarse de la obra del agustino Lope Fernández de Minaya, inscrita en la filosofía ascética, parece más adecuado situarlo en la corriente de literatura apocalíptica relacionada con el franciscanismo e identificarlo con la versión castellana del Libro de las tribulaciones del franciscano Juan de Rupescissa. Son datos indicativos de una posible conexión con las corrientes reformistas más radicales de signo apocalíptico. Se trataba de un texto con fuerte componente moralizante en que se expresaban violentas censuras hacia la Iglesia combinadas con reivindicaciones de reforma. Es sabido que en su versión castellana se difundió mucho durante el siglo XV y que los años de tribulaciones se identificaron con los comprendidos entre 1460 y 1465 , signados en Córdoba por la dificultad política y la violencia ${ }^{84}$. Por su parte, Constanza Rodríguez legaba en 1477 a este monasterio un libro de horas escrito en papel que tengo con que yo rezo y a su sobrina Constanza sus cuentas de azabache con que yo rezo $0^{85}$. La entrega de estos bienes denota la existencia de una red de contactos femeninos, sintonías espirituales y coincidencias en planteamientos de renovación eclesial que probablemente se habían plasmado con anterioridad en vínculos espirituales y personales, incluso quizá de servicio, reforzados mediante el legado testamentario. Con este tipo de transmisiones, además, las beatas difundían sus planteamientos espirituales, creaban estados de opinión y facilitaban a otras el acceso a su género de vida.

Hemos señalado que las beatas ejercieron funciones de ayuda a otras mujeres, funciones de apoyo a la autosuficiencia femenina en el ámbito de la vida cotidiana, con una importante dimensión de asistencia doméstica y acompañamiento, y de forma muy señalada en el ámbito económico mediante el ejercicio de la caridad o de papeles de autoridad en la transmisión de bienes como, por ejemplo, albaceas testamentarias. Son las primeras funciones documentadas en Córdoba y es muy significativa la conexión establecida a veces entre acompañamiento y papel de albacea ${ }^{86}$.

${ }^{82}$ Es conocida la importancia de las imágenes y objetos devotos en la espiritualidad femenina de estos siglos: J. Hamburger, The Visual.

${ }^{83}$ Era la única edición en castellano de la vida de San Francisco. J.M. Arcelus, Floreto.

${ }^{84}$ Edita una de las versiones de la obra: J. Guadalajara, Las profecías, pp. 427-441.

${ }^{85}$ AHPCProt, Oficio 14, leg. 3, cuad. 1, ff. 113 v-115r, 12v-15r; leg. 20, cuad. 7, ff. 23r-24r; ACC, Obras pías, caja 902; CMC, 1472-2.

${ }^{86}$ ACC, caja V, núm. 369; CMC, 1363, 1380 y 1425; AHPCProt, Oficio 14, leg. 32, cuad. 17, f. $60 \mathrm{v}$; leg. 33 , cuad. 13 , ff. $5 \mathrm{v}-7 \mathrm{v}$. 
Las relaciones de servicio podían derivar en una función de representación económica por parte de la beata respecto a otra mujer: significativamente, eran mujeres quienes se la encomendaban ${ }^{87}$. Suponemos que su papel como acogidas daría lugar asimismo a algún otro tipo de asistencia doméstica. Todas ellas fueron actividades a englobar en un concepto de cura animarum de carácter amplio y con componentes sexuados que pueden caracterizarse como originales en el contexto de las formas de dedicación apostólica. La actividad caritativa, uno de los elementos más destacados del apostolado beato, tuvo también una intensa dimensión femenina que cabe suponer en los hospitales pero que fue muy notoria en el ámbito doméstico-privado: además de la integración de mujeres pobres en las comunidades, las beatas podían acoger a otras en su compañía sin llegar a constituir un beaterio ${ }^{88}$ o bien mediaban en la vida cotidiana a favor de mujeres necesitadas; asimismo, dicha actuación de apoyo y ayuda material se dirigió a algunos monasterios femeninos. Por lo demás, el concepto mismo de communitas beata incluía la puesta en común de bienes que, aun respetando la propiedad privada de cada religiosa, integraba y favorecía materialmente a mujeres de muy diferente capacidad económica facultando el sustento y la autonomía material de las menos pudientes.

Esta dimensión pastoral, de caridad y de acompañamiento preferentemente femeninos, tanto en la vertiente relacional interna como en la acción exterior beata, constituye uno de los rasgos más característicos de esta forma de vida y una de sus razones explicativas. Desde esta perspectiva, la dedicación beata habría nacido con una vocación de abrir puertas a la libertad de las mujeres, en su dimensión individualista y relacional, de apoyar su autosuficiencia en su propio medio doméstico-cotidiano y su promoción, así como de trabajar por su bienestar. Y habría acabado configurando una red social femenina de apoyo mutuo. Pero esta notoria impresión de autosuficiencia que brota de las fuentes, ¿revela un deseo de separación del mundo?

Hubo sin duda un deseo de separación y de énfasis sexuado común a todas las dedicaciones beatas entendido como necesidad de abrirse ámbitos de libertad y concretado en una independencia real respecto a las estructuras de encuadramiento humano institucionalmente reconocidas. Partiendo de ahí, fueron distintos los grados de independencia y de sexuación buscados y logrados, en paralelo con sus diversas tipologías y con los procesos históricos en que participaron y que les afectaron. Pero es preciso considerar además que la implicación de las beatas con la ciudad constituyó otro de sus rasgos definidores más característicos. Esta implicación ofrece varias dimensiones de incidencia en la socialización y en la vida social urbanas.

Primero, aunque alcanzaron muy diferentes grados de repercusión en el marco urbano, su forma de vida recibió reconocimiento de autoridad constituyéndose en vía de socialización femenina admitida que desembocó en la forja de un nuevo rol social femenino, de un nuevo estado de vida con reconocimiento público que admitía la independencia vital, patrimonial y laboral de las mujeres y que podría caracterizarse como profesión. En el ámbito artesanal se documenta una realidad cercana a las beguinas de los Países Bajos, con beatas que ejercían un oficio - la alfayata Leonor Alfonso- o figuraban relacionadas con el artesanado cordobés, por parentesco o por ceder su vivienda para actividades gremiales, lo cual podría hacer suponer esta dedicación ${ }^{89}$, una realidad cuya amplitud social es difícil de calibrar. Pero también y sobre todo en una nueva dimensión de trabajo social de carácter multifacético que

${ }^{87}$ AHPCProt, Oficio 33, leg. 1, f. 250r-v.

${ }^{88}$ Beatriz Fernández legaba 100 maravedís a Isabel Rodríguez, pobre que vivía en su casa, por cargo que de ella tenía. AHPCProt, Oficio 14, leg. 32, cuad. 20, ff. 53r-55v.

${ }^{89}$ ACC, caja D, núm. 525; CMC, 1441.

ANUARIO DE Estudios MEDIEVALES, 42/2, julio-diciembre 2012, pp. 697-725

ISSN 0066-5061, doi:10.3989/aem.2012.42.2.06 
dignificaba el trabajo doméstico femenino y sus ámbitos de desarrollo otorgándoles una nueva relevancia sacra. Si el movimiento laico enfatizaba la dignidad del cuerpo y la palabra de las mujeres como ejemplo evangélico e instrumento de reforma y conversión, estas nuevas formas laborales y, en general, todas las actividades de las beatas, eran también manifestaciones de un apostolado social en clave sexuada porque aprovechaba los espacios, las maneras y los oficios tradicionalmente característicos de las mujeres. Una acción social muy orientada hacia los intereses y necesidades femeninos pero cuya visibilidad sacra y su compatibilización con actividades de interés social general como el trabajo en hospitales, el ejercicio de la caridad, tareas de animación espiritual general y, muy especialmente, su actividad de oración salvífica por los habitantes de la ciudad -mujeres y hombres-, contribuía a visibilizar y dignificar a las mujeres en su contexto urbano introduciendo modificaciones en la organización y percepción de lo social. Una actividad orante que se convirtió también, per se, en una profesión femenina, un oficio remunerado reconocido por la población urbana, aunque al menos en Córdoba su ejercicio aparezca especializado en relación con los grupos no privilegiados.

Las beatas abrieron así nuevas vías de socialización y profesionalización femeninas en el mundo urbano incidiendo directamente en la configuración del entramado social. Los datos recabados contradicen la afirmación, referida a las beguinas, de que no formaban parte de categorías socialmente reconocidas ${ }^{90}$. No lo fueron en Córdoba a nivel oficial-institucional, pero sí recibieron ese reconocimiento en la práctica social. La dedicación beata fue una vocación religiosa, pero también un instrumento de dignificación e inserción social, un estatus con la misma categoría que el matrimonio independiente de los circuitos de socialización al uso.

Esta incidencia sobre la sociedad urbana la lograron, en un segundo lugar, implicándose en los procesos de estructuración política de la ciudad, como paso a ver.

\subsection{Al servicio del ideal de comunidad cívica}

Aunque también en este ámbito se perciben diferentes situaciones y grados de implicación, es cierto que sobre todo en los inicios del movimiento el vínculo se perfila con nitidez. Hubo una implicación beata en los procesos de constitución política urbana, bien fuese en una dimensión de ejemplaridad o de acción expresa. Resulta evidente el alineamiento beato con un ideal de comunidad cívica al que ellas aportaron una caracterización sacra evangélica y que concretaron en su identificación con el sector pechero o los jurados populares, llevada al extremo de desarrollar una pastoral que, más allá de su especialización sexuada, fue pechera y marginal. Ofrecieron además nuevos modelos de agrupación humana, política y eclesial, un nuevo paradigma de Iglesia fundado en su plan reformista evangélico que, partiendo de la dignidad de las/os individuas/os en su capacidad de comunicación con Dios y de santificación personal, lo que en última instancia significaba trabajar por la emancipación del laicado y por perfilar una comunidad civil con identidad propia, proponía un ideal comunitario apostólico/sororal o fraterno además de la vida austera, la valoración del trabajo manual y de los sectores sociales marginados o en inferioridad: en su sentido amplio, el entero conjunto de la sociedad pechera urbana, sobre todo los trabajadores manuales; en el más restringido, los marginados y pobres; y, en lugar preferente, las mujeres.

Podría aducirse como argumento contrario a su carácter político el que la mayoritaria adscripción sociológica no privilegiada de las beatas obedeciese en sus

90 B. Delmaire, Les beguines, pp. 122-126; C. Neel, The Origins, pp. 240-259; W. Simons, Cities, p. 35. 
orígenes a los efectos de la gran crisis del siglo XIV y, a lo largo de todo su desarrollo, a algunas características demográficas estructurales de las ciudades medievales como que las mujeres se hallasen especialmente expuestas a la amenaza de pobreza y marginación social ${ }^{91}$. En este sentido, la vida beata pudo ser garantía de refugio y sustento, aunque esta función es documentalmente más notoria en el emparedamiento ${ }^{92}$. Por otra parte, el hecho señalado de que el fenómeno beato conectase con los inicios del crecimiento demográfico y urbano en clave de soltería femenina, un factor demográfico que no puede obviarse.

Sin negar el peso de estos condicionantes, se perfila con fuerza una vocación urbana de incidencia política sobre la ciudad. La implicación política de la simbiosis entre independencia personal y conciencia comunitaria y entre lo doméstico, lo íntimo y el activismo social aportadas por las beatas, perfiló una alternativa al fenómeno de polarización y jerarquización política urbana, a un proceso de aristocratización que, si bien parece haber sido característico de Córdoba casi desde los inicios de la colonización cristiana ${ }^{93}$, había iniciado un proceso de afianzamiento monopolístico a mediados del siglo XIV. Las beatas ofrecían modelos relacionales de signo evangélico-comunitario fundados en la sororidad, lo que, sumado a su origen social no privilegiado, constituía un potente instrumento al servicio de la concreción y visibilización sacras de la comunidad cívica precisamente a partir del Trescientos, momento en que ésta definía su fisonomía y propuestas frente al regimiento oligárquico. El peso específico del artesanado en su extracción sociológica inicial, un sector pujante en proceso de desarrollo, ofrece pistas valiosas en este sentido. Pero lo hicieron desde una conciencia de marginalidad que casi podríamos calificar como "militante". Con su sola presencia, contribuyeron a sacralizar -por lo tanto, a otorgar proyección social- ámbitos físicos y vivenciales de la urbe de consideración marginal desde la perspectiva de los parámetros dominantes. Fue así en la dimensión sociológica dada su calidad de mujeres y no privilegiadas y dado el hecho de que trabajasen a favor de los marginados sociales reivindicando su valor en la Iglesia, lo que indirectamente constituía también una reivindicación de un común progresivamente arrinconado por la aristocratización del gobierno urbano. La vocación por la marginalidad, entendida en esta dimensión de incidencia política, se desvela también en lo institucional, de ahí una de las posibles explicaciones de la pertinacia femenina en lo que podría denominarse "a-institucionalización". Y se desvela además en la dimensión topográfica.

Frente a unos monasterios femeninos hijos de un modelo de la Restauración con vocación urbanística central, instalados en la Villa, el fenómeno beato surgió y se difundió preferentemente por la Ajerquía. Sin olvidar que la temprana realidad grupal de los emparedamientos de la Villa sumada a la existencia de dos monasterios femeninos en su territorio a finales del siglo XIV acaso saturasen la presencia femenina en esta zona urbana, se plantean otras razones, sin duda de espacio, aunque una lectura topográfica en clave religiosa y de identidad ofrece asimismo explicaciones. La mayor proliferación de beatas espontáneas se dio en las collaciones de San Llorente, Santa Marina y Magdalena, espacios urbanos de carácter residencial y popular; las dos primeras eran las más grandes y menos pobladas de la Ajerquía ${ }^{94}$. Compartían un carácter excéntrico y próximo a la muralla.

Este carácter excéntrico y de relativa despoblación ofrecía una correspondencia de fuga mundi y marginalidad topográfica en femenino a la tendencia eremítica

\footnotetext{
${ }^{91}$ Y. Barel, La ciudad; P.H. Cullum, "And Hir Name".

92 M.M. Graña, Religiosas.

93 M. González Jiménez, Ciudades, pp. 246 y ss.

94 J.M. Escobar, Córdoba, pp. 252 y 76.
} 
masculina de implantación serrana extramuros, marginalidad acentuada por la importante red hospitalaria implantada en este sector urbano y que debió constituir otro factor impulsor de beaterios. Por lo demás, la marginalidad urbanística contribuía a visibilizar una vocación de independencia convertida en uno de los factores explicativos clave de las creaciones laicas y su peculiar evolución, aspectos especialmente notorios entre beatas individuales y microbeaterios, que mantuvieron su postura al margen de las estructuras eclesiásticas como signos evangélico-religiosos independientes en un fenómeno llamativo de permanencia temporal.

Además de los ámbitos sociológica y topográficamente marginales, las beatas otorgaron visibilidad sacra y significación sociorreligiosa a la esfera doméstica de las capas populares. Resultados sin duda inseparables de su vocación reformista de incidencia activa en el mundo como posible propuesta de reforma política y, sin duda, de dignificación del común y de los sectores urbanos marginales: los pobres y, desde la perspectiva institucional y del poder, las mujeres. Inspiración carismática y factor sociopolítico se amoldaron para ofrecer proyectos definidos de incidencia en el mundo.

En una segunda fase del movimiento espontáneo siguieron manifestándose estos aspectos y se sumaron otros, entre ellos la elevación del nivel social de las creadoras de los beaterios y las primeras referencias a parientas de jurados. Un vínculo que recibió gran importancia al figurar explícitamente en la denominación de buena parte de las comunidades.

Se visibilizaba y sacralizaba así la figura del jurado de raigambre más popular dado que no hay identificación de apellido, lo que conllevaba el ejercicio de una función de arraigo urbano de los sectores inferiores del gobierno concejil en los ámbitos cuya representatividad ejercían. El mecanismo fue similar al de las fundaciones monásticas y la cuestión radicaría en saber si obedecieron a comportamientos emuladores de la nobleza urbana, que había emprendido con anterioridad sus fundaciones de monjas en sus casas residenciales ${ }^{95}$. Sin negar esta posibilidad en un marco de creciente aristocratización mental, llama la atención el hecho de que fueran las hijas de los jurados las impulsoras de estos espacios, no sus parientes masculinos, que quizá hubieran preferido establecer instituciones o formas de vida perdurables y no vitalicias. Ellas, las únicas nombradas en la documentación, quisieron hacer visible el vínculo paterno y familiar. Participaban así de la función sociopolítica ciudadana del padre en una dimensión de refuerzo popular al tratarse de jurados no aristocráticos. Lo hicieron en un contexto de tensiones intensas entre unos jurados muy conscientes de su misión de representación del común de la ciudad frente a los abusos de los poderosos y una oligarquía que tendía a concentrar cada vez más poder en la institución municipal ${ }^{96}$. El empeño pacificador y reivindicativo de los jurados hallaba su visibilidad sacra en las comunidades evangélicas y populares beatas así como en la acogida en ellas a mujeres de los sectores inferiores de la sociedad urbana. El posible carácter de "toque de atención" política que estos beaterios vitalicios pudieron compartir con otro tipo de hermandades temporales coetáneas iría en esta dirección.

En ambos casos, la vocación urbana de la vida beata inicial y la dimensión urbanística de su proyección religiosa fueron aspectos característicos. Salvo unas formas individuales bastante repartidas por el entramado urbano, las comunidades se instalaron en collaciones cuya infraestructura interna se creó básicamente en época

95 M.M. Graña, Religiosas.

${ }^{96}$ M. Nieto Cumplido, Luchas, pp. 50-51; F. Mazo, Problemas, p. 208. Es conocida la capacidad asociativa brindada por la propia dinámica urbana, en concreto de los grupos populares. J.I. Ruiz de la Peña, Las solidaridades, pp. 51-73; M. Asenjo, Concordia, pp. 105-140.

ANUARIO de Estudios Medievales, 42/2, julio-diciembre 2012, pp. 697-725

ISSN 0066-5061, doi:10.3989/aem.2012.42.2.06 
cristiana, con una lógica nueva. El ideal de regeneración reformista halló así su ámbito de plasmación preferente en la que constituía la nueva ciudad cristiana surgida del impulso local. En estrecha conexión se sitúan los dos vínculos sociales preferentes: el artesanal en los inicios del fenómeno beato y el concejil en fase posterior. Evidencian el arraigo de las nuevas propuestas espirituales en los grupos urbanos más dinámicos y con una vocación de visibilización y significación, lo que encaja en el emplazamiento de la Ajerquía, el sector "nuevo" y más propiamente local de la ciudad, en plena fase expansiva ${ }^{97}$, como signos de una conciencia urbana también nueva y naciente. Ello se plasmó en lo urbanístico: algunos beaterios se identificaron con elementos topográficos -calle, collación u otro lugar- y a veces incidieron sobre esa realidad, transformándola y dándole nombre, como fruto de procesos de proyección sociorreligiosa unidos al crecimiento urbano: las beatas del Cañuelo, denominadas como su lugar de ubicación, acabaron nombrando a la calle, quizá incluso generándola en torno suyo; las "beatas hijas del jurado Nicolás Rodríguez" pasaron a denominarse "beatas del Zarco", nombre de su calle, desde finales de la década de $1470^{98}$. Por lo demás, los espacios religiosos laicos contribuían a sacralizar de forma difusa la trama urbana a través de su medio residencial habitual, la vivienda privada, estuvieran o no en contacto con el mundo.

\section{REFLEXIONES FINALES}

El análisis del fenómeno beato espontáneo en un marco como el cordobés muestra que sus espacios religiosos fueron reforzadores de la fisonomía cristiana urbana y de la vinculación de los sectores inferiores y más representativos del concejo con el cuerpo de la ciudad. Al servicio de la identidad de la metrópoli en un momento de expansión demográfica y creación urbanística en las áreas de mayor crecimiento, respondieron a una conciencia urbana surgida de las bases locales, no impuesta por las fuerzas del poder, que revela el afianzamiento de una cristiandad local con intereses propios y no condicionados -salvo para rechazarlo- por el esquema religioso implantado con la Restauración. Bajo el horizonte eclesial de la reforma de la Iglesia en su dimensión institucional y social, su estrecha conexión con el fenómeno eremítico serrano masculino podría hacer pensar en una posible reivindicación conjunta de las raíces eremíticas de la vida religiosa local como clave de identidad cordobesa frente a la imposición eclesiológica de la Restauración. Si las principales señas identificativas de este segundo proyecto eran asumidas por los hombres de la oligarquía todavía en el último tercio del siglo XIV, el movimiento beato fue de raigambre sociológica popular y se vinculó a sectores representativos de la ciudadanía urbana en un fenómeno de sacralización de los mismos, del común de la ciudad y de las estructuras relacionales horizontales en un contexto político de pérdida de terreno de los menudos ante la oligarquización creciente del gobierno concejil. Asimismo, se detecta el rechazo del modelo religioso de la Restauración, el modelo institucional del poder plasmado en el aristocrático monasterio de Santa Clara, polo opuesto de las tipologías beatas; incluso en los beaterios más jerarquizados los intereses vinculados a los jurados parecen haber querido contrarrestarlo en su opción por espiritualidades reformistas como la jerónima.

De ello puede inferirse un componente reivindicativo que no agota en sí todas las posibles explicaciones del fenómeno, pero que arroja mucha luz sobre él.

97 J.M. Escobar, Córdoba, p. 82.

${ }^{98}$ AHPCProt, Oficio 14, leg. 5, cuad. 7, ff. 12r-13v. 
Reivindicativo del valor de lo laico y lo a-institucional frente a lo eclesiástico e institucional, de lo local frente a lo foráneo, pero también de lo popular frente a lo aristocrático en un contexto de progresiva escalada del control ejercido por la nobleza sobre la ciudad y el realengo; ello sin olvidar la potenciación de lo femenino. Desde esta perspectiva, la dedicación beata figuraría como manifestación de la comunidad cívica, cuya emergencia frente al regimiento oligárquico fue uno de los fenómenos característicos de las ciudades castellanas en el siglo XIV. Se pondría así de manifiesto el peso decisivo de otro importante ámbito de realidad urbana: la dinámica configuradora del sistema político urbano bajomedieval y el hecho de que las dedicaciones femeninas laicas apoyasen la formulación de proyectos políticos alternativos al señorial imperante.

Las beatas entendieron como parte principal de ese proyecto político la libertad de las mujeres y la dignificación de su sexo en un contexto canónico-eclesiástico de marcada misoginia. Con sus propuestas y práctica de vida, contribuyeron a visibilizar y potenciar la "sociedad femenina" inserta en el cuerpo urbano, abrieron nuevas vías de socialización y profesionalización femeninas, atendieron a las mujeres en sus necesidades, ofrecieron un simbólico femenino a la comunidad urbana y lograron reconocerse y hacerse reconocer autoridad. Si resulta evidente la conexión entre el origen del movimiento religioso femenino laico y el nacimiento y consolidación de las ciudades y la identidad ciudadana en Andalucía, estos procesos fueron inseparables de una reivindicación de lo femenino que halló en el mundo urbano su medio de expresión ideal.

\section{BIBLIOGRAFÍA CITADA}

Arcelus, Juana Mary, Floreto de Sant Francisco (Sevilla, 1492), Madrid, Fundación Universitaria Española - Universidad Pontificia de Salamanca, 1998.

Asenjo González, María, Concordia, pactos y acuerdos en la sociedad política urbana de la Castilla bajomedieval, en Foronda, F.; Carrasco Manchado, A.I. (dirs.), El contrato político en la Corona de Castilla. Cultura y sociedad políticas entre los siglos X al XVI, Madrid, Dykinson, 2008, pp. 125-157.

Barel, Yves, La ciudad medieval. Sistema social-sistema urbano, Madrid, Instituto de Estudios de Administración Local, 1981.

Beceiro Pita, Isabel; Córdoba de la Llave, Ricardo, Parentesco, poder y mentalidad. La nobleza castellana (siglos XII-XV), Madrid, CSIC, 1990.

Bennassar, Bartolomé, Contestación, carisma y cambio de estructuras (En la Iglesia y en la sociedad), Madrid, El Perpetuo Socorro, 1970.

Benvenuti Papi, Anna, “In castro poenitentiae”. Santità e società femminile nell Italia medievale, Roma, Herder, 1990.

Bornstein, Daniel, Donne e religione nell'Italia tardomedievale, en Bornstein, D.; Rusconi, R. (eds.), Mistiche e devote nell'Italia tardomedievale, Nápoles, Liguori, 1992, pp. 237-261.

Botinas, Elena; Cabaleiro, Julia; Durán, Maria del Angels, Les beguines. La Raó il.luminada per Amor, Barcelona, Publicacions de l'Abadia de Montserrat, 2002.

Bynum, Carolyne W., Jesus as Mother. Studies in the Spirituality of the High Middle Ages, Berkeley - Los Angeles - Londres, University of California Press, 1982.

Bynum, Carolyne W., Fragmentation and Redemption. Essays on Gender and the Human Body in Medieval Religion, Nueva York, Zone Books, 1991.

ANUARIO de Estudios Medievales, 42/2, julio-diciembre 2012, pp. 697-725

ISSN 0066-5061, doi:10.3989/aem.2012.42.2.06 
Cabrera Sánchez, Margarita, Nobleza, oligarquía y poder en Córdoba al final de la Edad Media, Córdoba, Universidad de Córdoba - CajaSur, 1998.

Cátedra, Pedro M.; Rojo, Anastasio, Bibliotecas y lecturas de mujeres. Siglo XVI, Salamanca, Instituto de Historia del Libro y de la Lectura, 2004.

Collantes de Terán, Antonio, Sevilla en la Baja Edad Media. La ciudad y sus hombres, Sevilla, Universidad de Sevilla, 1977.

Cullum, P.H., "And Hir Name was Charité". Charitable Giving by and for Women in Late Medieval Yorkshire, en Goldberg, P.J.P. (ed.), Woman is a Worthy Wight. Women in English Society, c. 1200-1500, Gloucestershire, S. Sutton, 1992, pp. 182-211.

Chenu, Marie-Dominique, El despertar evangélico, en Little, L.K.; Rosenwein, B.H. (eds.), La Edad Media a debate, Madrid, Akal, pp. 478-505.

Delmaire, Bernard, Les beguines dans le Nord de la France au premièr siècle de leur histoire (vers 1230-vers 1350), en Parisse, M. (ed.), Les religieuses en France au XIIIe siècle, Nancy, Presses Universitaires de Nancy, 1985, pp. 122-162.

Epiney-Burgard, Georgette; Zum Brunn, Emilie, Mujeres trovadoras de Dios. Una tradición silenciada en la Europa medieval, Barcelona, Paidós Ibérica, 1998.

Escobar Camacho, José Manuel, Córdoba en la Baja Edad Media (Evolución urbana de la ciudad), Córdoba, Caja Provincial de Ahorros, 1989.

Flores Varela, Carlos, La evolución de la población urbana de Andalucía en los siglos XV y XVI, "En la España Medieval” 28 (2005), pp. 97-125.

Fortea Pérez, José Ignacio, Córdoba en el siglo XVI: las bases demográficas y económicas de una expansión urbana, Córdoba, Caja de Ahorros, 1980.

García de Cortázar, José Ángel (ed.), Cristianismo marginado: rebeldes, excluidos, perseguidos, Del año 1000 al año 1500, vol. II, Madrid, Fundación Santa María la Real, Centro de Estudios del Románico - Polifemo, 1999.

Giddens, Anthony, Sociology, Cambridge, Polity Press, 1993.

Gieben, Servus, Vita comunitaria tra i penitenti francescani nei Paesi Basi, en Pazzelli, R.; Temperini, L. (eds.), Prime manifestazioni di vita comunitaria maschile e femminile nel movimento francescano della Penitenza (1215-1447), Roma, Commissione Storica Internazionale TOR, 1982, pp. 147-160.

González Jiménez, Manuel, El concejo de Carmona a fines de la Edad Media, Sevilla, Diputación Provincial de Sevilla, 1973.

González Jiménez, Manuel, Ciudades y concejos andaluces en la Edad Media: gobierno urbano, en Concejos y ciudades en la Edad Media hispánica, II Congreso de Estudios Medievales de la Fundación Sánchez-Albornoz, Ávila, Fundación Sánchez-Albornoz, 1990, pp. 237-274.

Graña Cid, María del Mar, Espacios de vida espiritual de mujeres (Obispado de Córdoba, 1260-1550), Tesis doctoral, Universidad Complutense de Madrid, 2008.

Graña Cid, María del Mar, Religiosas y ciudades. La espiritualidad femenina en la construcción sociopolítica urbana bajomedieval (Córdoba, siglos XIIIXVI), Córdoba, Asociación Hispánica de Estudios Franciscanos, 2010.

Grundmann, Herbert, Movimenti religiosi nel Medioevo. Ricerche sui nessi storici tra l'eresia, gli ordini mendicanti e il movimento religioso femminile nel XII e XIII secolo e sui presupposti storici della mistica tedesca, Bolonia, Il Mulino, 1980.

Guadalajara Medina, José, Las profecías del Anticristo en la Edad Media, Madrid, Gredos, 1996.

Hamburger, Jeffrey, The Visual and the Visionary: the Image in Late Medieval Monastic Devotions, "Viator" 20 (1989), pp. 161-182.

ANUARIo de Estudios Medievales, 42/2, julio-diciembre 2012, pp. 697-725

ISSN 0066-5061, doi:10.3989/aem.2012.42.2.06 
Heers, Jacques, El clan familiar en la Edad Media, Barcelona, Labor, 1978.

Herlihy, David, Opera Muliebria. Women and Work in Medieval Europe, Nueva York, Temple University Press, 1990.

López, Juan, Tercera parte de la Historia General de Sancto Domingo y de su Orden de Predicadores, Valladolid, por Francisco Fernandez de Cordoua y a su costa, 1613.

Lynch, Catherine A., Individuals, Families and Communities in Europe, 1200-1800. The Urban Foundations of Western Society, Cambridge, Cambridge University Press, 2003.

Mackay, Angus, Averroístas y marginadas, en La sociedad medieval andaluza: grupos no privilegiados, III Coloquio de Historia Medieval de Andalucía, Jaén, Diputación Provincial - Instituto de Cultura, 1984, pp. 247-261.

Manselli, Raoul, La Chiesa e il francescanesimo femminile, en Movimento religioso femminile e francescanesimo nel secolo XIII, Assisi, Società Internazionale di Studi Francescani, 1980, pp. 239-261.

Mazo Romero, Fernando, Problemas internos y tensiones sociales en el municipio cordobés durante la primera mitad del siglo XV, en Torres Delgado, Cristóbal (ed.), Andalucía medieval: nuevos estudios, Córdoba, Monte de Piedad y Caja de Ahorros, 1980, pp. 175-210.

McLaughlin, Eleanor, Equality of Souls, Inequality of Sexes: Woman in Medieval Theology, en Ruether, R. (ed.), Religion and Sexism: Images of Women in the Jewish and Christian Traditions, Nueva York, Wipf and Stock, 1974, pp. 213-266.

McNamara, Jo Ann, Hermanas en armas. Dos milenios de historia de las monjas católicas, Barcelona, Herder, 1999.

Meersseman, Gilles Gerard, I penitenti nei secoli XI e XII, en I laici nella 'Societas Christiana’ dei secoli XI e XII, Milán, Vita e Pensiero, 1968, pp. 306-339.

Miura Andrades, José María, Formas de vida religiosa femenina en la Andalucía medieval. Emparedadas y beatas, en Muñoz, Á.; Graña, M.M. (eds.), Religiosidad femenina: expectativas y realidades (ss. VIII-XVIII), Madrid, A.C. Al-Mudayna, 1991, pp. 139-164.

Muñoz Fernández, Ángela, Beatas y santas neocastellanas: ambivalencias de la religión y políticas correctoras del poder (ss. XIV-XVII), Madrid, Dirección General de la Mujer, 1994.

Muñoz Fernández, Ángela, Subjetividad femenina y la resignificación en el campo del parentesco espiritual, "Duoda. Revista d'Estudis Feministas" 11 (1996), pp. 39-60.

Muzzarelli, Maria Giuseppina, Un'introduzione dalla storiografia, en Muzzarelli, M.G.; Galetti, P.; Andreolli, B. (eds.), Donne e lavoro nell'Italia medievale, Torino, Rosenberg and Sellier, 1991.

Neel, Carol, The Origins of the Beguines, en Bennet, J. (ed.), Sisters and Workers in the Middle Ages, Chicago, University of Chicago Press, 1989, pp. 240-259.

Nieto Cumplido, Manuel, Luchas nobiliarias y movimientos populares en Córdoba a fines del siglo XIV, en Riu Riu, Manuel; Torres Delgado, Cristóbal; Nieto Cumplido, Manuel, Tres estudios de historia medieval andaluza, Córdoba, Monte de Piedad y Caja de Ahorros, 1982, pp. 10-65.

Nieto Soria, José Manuel, Los prolegómenos eclesiásticos de las hermandades políticas, en Foronda, F.; Carrasco, A.I. (dirs.), El contrato político en la Corona de Castilla: cultura y sociedad políticas entre los siglos X y XVI, Madrid, Dykinson, 2008, pp. 43-63.

Palacios Alcalde, María, Las beatas ante la Inquisición, "Hispania Sacra” 40 (1988), pp. 107-131.

Pérez González, Silvia M., La mujer en la Sevilla de finales de la Edad Media: solte-

ANUARIO DE Estudios Medievales, 42/2, julio-diciembre 2012, pp. 697-725

ISSN 0066-5061, doi:10.3989/aem.2012.42.2.06 
ras, casadas y vírgenes consagradas, Sevilla, Universidad de Sevilla, 2005.

Quintanilla Raso, M. Concepción, Estructuras sociales y familiares y papel político de la nobleza cordobesa (siglos XIV y XV), "En la España Medieval" 3 (1982), pp. 331-352.

Rivera Garretas, M. Milagros, La diferencia sexual en la historia, Valencia, Universitat de València, 2005.

Rivera Garretas, M. Milagros, La política sexual, en Rivera, M.M. (coord.), Las relaciones en la historia de la Europa medieval, Valencia, Tirant lo Blanch, 2006, pp. 139-204.

Rodríguez Molina, José, Los no privilegiados en Jaén (siglos XIV y XV), en La sociedad medieval andaluza: grupos no privilegiados, III Coloquio de Historia Medieval de Andalucía, Jaén, Diputación Provincial - Instituto de Cultura, 1984, pp. 133-163.

Ruano, Francisco, Casa de Cabrera en Córdoba. Obra genealógica histórica, C. Muñoz Torralbo; S., García-Mauriño Martínez (eds.), Córdoba, Diputación Provincial, 1994.

Ruiz de la Peña, Juan Ignacio, Las solidaridades vecinales en la Corona de Castilla (ss. XII-XV), en Cofradías, gremios, solidaridades en la Europa medieval, XIX Semana de Estudios Medievales, Pamplona, Departamento de Educación y Cultura, 1993, pp. 51-73.

Rusconi, Roberto (ed.), Il movimento religioso femminile in Umbria nei secoli XIIIXIV, Florencia, Fondazione CISAM, 1984.

Sánchez Herrero, José, La religiosidad popular en la Baja Edad Media andaluza, en Homenaje a Alfonso Trujillo, Santa Cruz de Tenerife, Aula de Cultura del Excmo. Ayuntamiento, 1982, vol. II, pp. 278-330.

Santonja, Pedro, Mujeres religiosas: beatas y beguinas en la Edad Media. Textos satíricos y misóginos, "Anales de la Universidad de Alicante. Historia Medieval" 14 (2003-2006), pp. 209-228.

Simons, Walter, Cities of Ladies. Beguine Communities in the Medieval Low Countries, 1200-1565, Filadelfia, University of Pennsylvania Press, 2003.

Wemple, Suzanne F., Women in Frankish Society. Marriage and the Cloister, 500 to 900, Filadelfia, University of Pennsylvania Press, 1991.

Fecha de recepción del artículo: enero 2011

Fecha de aceptación y versión final: diciembre 2011 
